\title{
Some pioneers of European human genetics
}

\author{
Peter S Harper*
}

Some of the pioneers of human genetics across Europe are described, based on a series of 100 recorded interviews made by the author. These interviews, and the memories of earlier workers in the field recalled by interviewees, provide a vivid picture, albeit incomplete, of the early years of human and medical genetics. From small beginnings in the immediate post-World War 2 years, human genetics grew rapidly across many European countries, a powerful factor being the development of human cytogenetics, stimulated by concerns over the risks of radiation exposure. Medical applications soon followed, with the recognition of human chromosome abnormalities, the need for genetic counselling, the possibility of prenatal diagnosis and later, the applications of human molecular genetics. The evolution of the field has been strongly influenced by the characters and interests of the relatively small number of founding workers in different European countries, as well as by wider social, medical and scientific factors in the individual countries.

European Journal of Human Genetics advance online publication, 10 May 2017; doi:10.1038/ejhg.2017.47

\section{INTRODUCTION}

The 50th anniversary of the European Society of Human Genetics (ESHG) provides a good opportunity to look back on how the field of human and medical genetics began, and how it has developed over the subsequent half century. The request from the ESHG Board that I should write an informal article describing some of the founders or other pioneers of the field, as seen from the perspective of my series of 100 recorded interviews, is a challenge, especially given the uneven geographical coverage of these interviews, the use mainly of English as the interview language, and the fact that some of the earliest founders are no longer living.

The ESHG Board recognised these difficulties, as is clear from the request itself:

'You have been working on interviews of many European geneticists, on the EHSG and the history of genetics in Europe and we thought this would be a great opportunity to let all the ESHG members and beyond participate in your work and your collection. Would it be feasible for you to work on a manuscript based on these interviews? It should be entertaining, not too light of course, but in an easy way telling stories and history of European genetics; of course it will never cover all aspects, this is not the implication, but it should show fragments of the developments and of the people behind.'

So here are what I hope will be some readable fragments of the beginnings of human genetics in Europe, and I hope that these will encourage others to expand them and to fill in the many gaps which inevitably exist, especially for those countries, which have been less fully recognised internationally, or where English is less used by older generations.

Actually, the gaps in the picture are less unbridgeable than it might seem initially, as I realised when undertaking the interview series. Many of the older workers in the field who I interviewed, even when not claiming to be true founders themselves, had been taught or trained by people who were, and whose academic careers stretched back to the pre-war decades when human genetics did not yet exist as a differentiated scientific discipline, let alone a medical specialty. The interviews provide numerous and vivid accounts of such people, now long deceased; although the passage of time may have resulted in some loss of accuracy, this has also allowed a more critical attitude to emerge than might have been possible in an interview with the individuals themselves; as well as abundant, often amusing anecdotes, which can be found in the individual transcripts.

\section{THE INTERVIEW SERIES}

As this article is based very largely on my own interview series, it is worth saying a few words about this. First, I must make the disclaimer that I am not a trained historian, something that initially earned me the stern disapproval of some of those who are! My answer to such critics was first, that no card-carrying historians, at least across Europe, were undertaking a comparable interview programme, but also that after a career of nearly 50 years in medical genetics, I had accumulated at least 30000 hours of interviewing experience as part of my daily work of genetic counselling, which was likely also to have been of some help in interviewing colleagues in the field!

How did I start? In 2003, soon after realising that the history of human genetics was in serious danger of being almost entirely lost, and helping, with colleagues, to initiate the Genetics and Medicine Historical Network, (Genmedhist), and its website (www.genmedhist. org), I realised that if recorded interviews were to be done at all I would have, at least initially, to do them myself. With a large number of potential interviewees, no funding or other assistance, but with a considerable amount of that most precious commodity, time, (I had recently stepped down as Head of Department), I set out with a small minidisc recorder and a simple digital camera to embark on my first interviews. In this article, as previously, I have assigned a number, given in square brackets [-] to each interview, based on chronological order. The complete series can be found on the Genmedhist website (www.genmedhist.org/interviews) and a summary and general account in my 'core' paper on the series (Harper). ${ }^{1}$

University Research Professor (Emeritus) in Human Genetics, Institute of Medical Genetics, School of Medicine, Cardiff University, Cardiff, UK

${ }^{*}$ Correspondence: Professor PS Harper, University Research Professor in Human Genetics, Institute of Medical Genetics, School of Medicine, Cardiff University, Heath Park, Cardiff, CF14 4XN, Wales, UK. Tel: + 44 2920753546; E-mail: HarperPS@cardiff.ac.uk

Received 12 January 2017; accepted 7 March 2017 
Who to choose? I decided to follow the route of 'rescue archaeology' and to begin with the oldest and frailest, choosing Paul Polani [01], (Figure 1), then almost 90 and the last surviving member of the true founders of human and medical genetics in Britain, as the most urgent. His fascinating account of his life and career, starting in Italy and developing fully in Britain, can be both read and heard in the transcript and audioclip preserved on the Genmedhist website (www. genmedhist.org/interviews).

Incidentally, I need not have worried about 'fragility' in Paul's case. Insisting on meeting me at the train station on an icy Winter's day, he drove me to his home just outside London, and after around 5 hours of conversation, including a 2 hour recording, was completely fresh (unlike myself). At the end he insisted on taking me for dinner at his favourite Italian restaurant, where the staff touchingly fell at his feet as if he were a deity. After a most excellent meal and a considerable amount of wine, he drove me (safely) back to the station - a memorable beginning to the interview series!

Perhaps, this experience can give a practical hint to others undertaking interviews: leave plenty of time. Although a very few interviewees may be somewhat laconic, most proceed spontaneously once started and the process is more one of delicate steering, with judicious silence perhaps the main contribution of the interviewer, though I always took with me a short list of key points to cover, in case they were forgotten. Also, most people wanted to talk more widely after the interview was over and often to show me records, books and so on, whose future they were concerned for; they were almost always glad to have the chance of reconnecting with their old field of work.

After the first few interviews I began to realise that most of those I was seeing had played key roles in the beginnings of human cytogenetics, mainly in the late 1950s and the 1960s. Having now in my project reached early 2004, I could see that that there might be merit in concentrating on this topic, especially since the 50th anniversary of the discovery of the correct human chromosome number in 1956 was approaching, and since most of those involved in this were European rather than living in geographically and financially inaccessible America. So I changed my initial 'rescue' plan and was fortunately able to interview the majority of those still living from this period, as can be seen in my 2006 book 'First Years of Human Chromosomes' (Harper), ${ }^{2}$ which also contains a CD with audioclips from 10 of these interviews. Being no expert myself in cytogenetics, I felt embarrassed initially by this role, but the

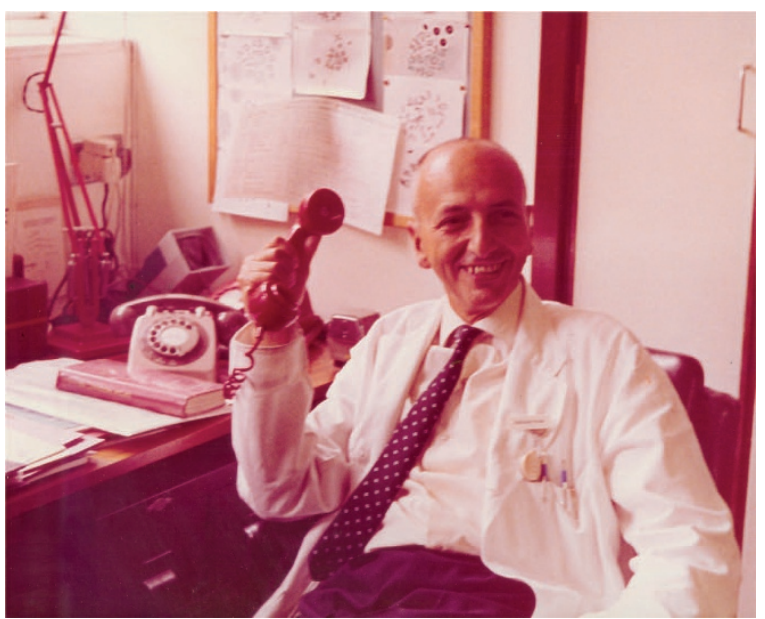

Figure 1 Paul Emanuel Polani (1914-2006). Courtesy of Paediatric Research Unit, Guy's Hospital, London. cytogeneticists proved to be a patient and tolerant group of people, who were surprisingly complimentary about the end result.

After the 1956 anniversary had passed, I reverted to my original plan, aiming to cover as fully as possible the development of the field across continental Europe. Fortunately there were now modest funding possibilities for travel, albeit informal ones, as I was still being asked to lecture on my previous research areas, such as Huntington's disease and myotonic dystrophy, whereas a few brave (forward-looking?) centres were even starting to ask me to talk on historical topics. My approach was to look at the map of Europe and identify which key individuals were living near my place of official invitation, shamelessly utilising the goodwill and local knowledge of my hosts to achieve these interviews.

In this way a patchy framework for the history of human genetics gradually began to assemble itself, though its fragmentary nature was evident in every visit resulting in me being given a list of other names of workers nearby whom I should interview. I had to plead that a single person such as myself could not possibly undertake this, and that a full history of human genetics across Europe could only be achieved by a multifocal, country by country initiative involving both geneticists and historians, and preferably with some international coordination provided by an organisation such as ESHG.

By 2008 I had begun to realise that, although the number of recorded interviews was still increasing, there was a growing backlog of work involving transcription, correction and finalising interviews for the web. This last task was especially demanding, especially since it often involved further consent, since I had promised interviewees that I would re-contact them if the interviews were to be made public in their lifetime. Remarkably, hardly any declined this. So, since funding for help with these tasks had been definitively refused, I had no choice but to halt new interviews and do the work myself, using what clerical help my generous but overstretched former department could give me. The time from interview to completion proved to vary greatly, sometimes taking up to 10 years!

When I began interviews again about 2 years later, I realised that the field of human molecular genetics, which I had myself been in at the beginnings of, was now itself 'becoming history'. Students were speaking of 'the old days when the Huntington's gene was isolated', whereas for me this still seemed like just a few days ago! So here was a new group of 'pioneers' which my previous interviews had hardly touched.

Added to this, a whole group of people who I had not interviewed because I felt they were 'too young', (I had previously loosely considered as 'old' those older than myself!) were now, disconcertingly for me, starting to retire. This further convinced me that I had undertaken a task impossible for a single individual, so I decided to focus on some of the key figures in human molecular genetics, and then to conclude the series once it had reached the arbitrary but satisfying number of 100 .

With hindsight, I now realise how fortunate I have been in living long enough to finally reach this target, to see the end results placed on the Genmedhist website (now itself under the auspices of ESHG and accessible via its own website as well as from www.genmedhist.org), and for my brain still to be functioning sufficiently to write some further accounts, such as this one, to bring the series to the attention of the wider human genetics community and to others. A paper summarising the interview series has just been published (Harper). ${ }^{1}$

\section{HUMAN GENETICS ACROSS EUROPE}

When considering an entire continent such as Europe, with its complex and multi-stranded social, cultural and scientific history, it 
a

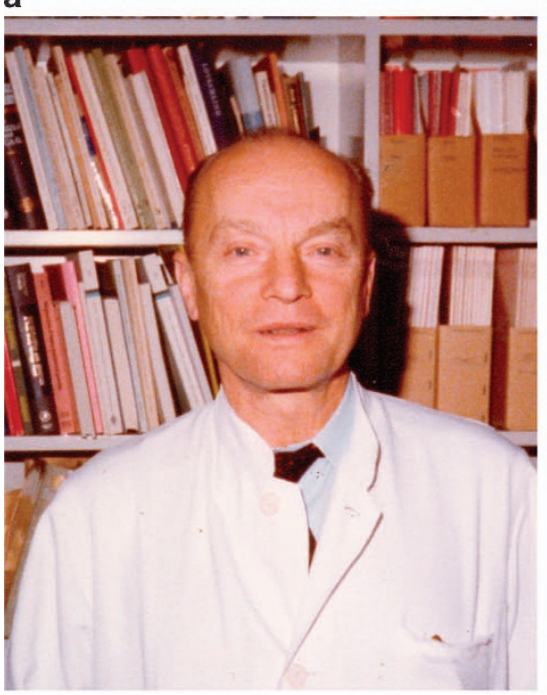

b

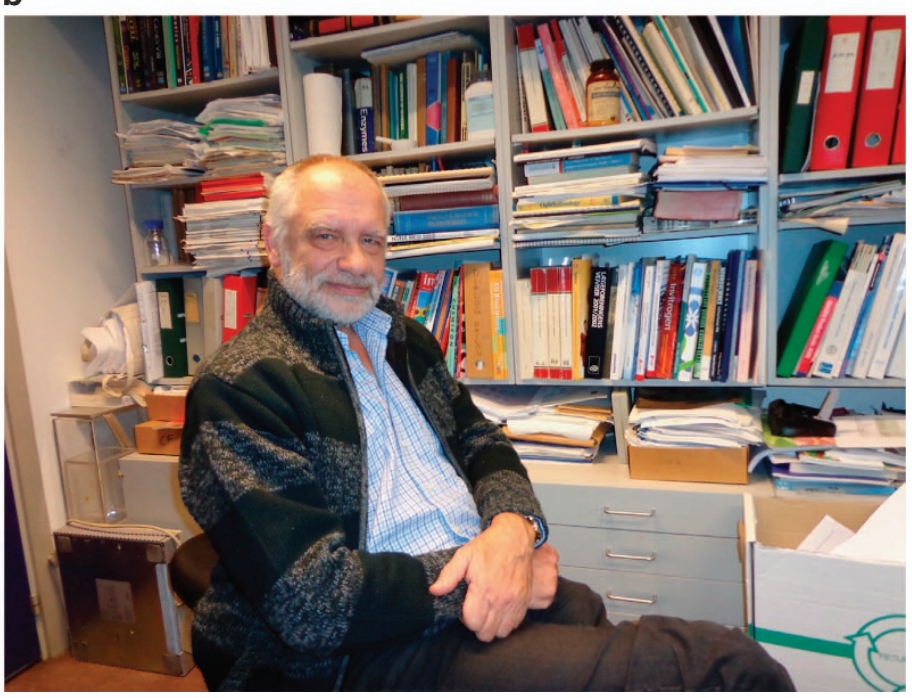

Figure 2 (a) Jan Mohr (1921-2009), courtesy of Hans Eiberg, Copenhagen. (b) Hans Eiberg (Born 1945).

does not make sense to take a purely linear approach to the development of human genetics. Indeed, as the interview series progressed, the multifocal origins of the field became increasingly apparent and future historians will need to take this complexity into account, rather than seeking to fit the different patterns observed into a single model. So I shall here take principally a country by country approach, necessarily very incomplete but hopefully reasonably accurate, though it will certainly need modifying as the topic becomes better documented, both from interviews and from written records. The book edited by Dronamraju ${ }^{3}$ contains a number of earlier accounts from individual countries.

An appropriate grouping of countries with which to begin would seem to be that of Scandinavia, including Finland, though those from outside the region generally have a somewhat simplistic idea of these countries as being rather uniform in scientific as well as social terms, whereas there are some marked differences as well as affinities between them in the development of human and medical genetics.

\section{Denmark}

In the Summers of 2004 and 2005 I undertook rather extensive visits to Denmark, Sweden and Norway, made possible in part by an invitation from the Mendelian Society of Lund, probably the oldest Society for genetics in the world (Harper). ${ }^{4}$ The interview with Jan Mohr, [51] based in Copenhagen for most of his career, was actually carried out in Oslo, to where he had retired; this was one of the key interviews for the history of European human genetics generally, in view of his founding role for ESHG, about which I have written elsewhere in this 'special issue' (Harper). ${ }^{5}$ It was also a great pleasure in personal terms to have this conversation, as I had previously been somewhat critical of him at the time of the reform of the Society beginning in 1988, when it met in Cardiff. A further link was our mutual interest in the mapping of the myotonic dystrophy gene, with linkage to the secretor and Lutheran blood group loci, the first example of autosomal genetic linkage in humans, found by Mohr as long ago as 1951 (Mohr J). ${ }^{6}$

The history of Mohr's long career in human genetics encompasses both Norway and Denmark, but taking the Danish part first, he initially worked with and then in 1966 succeeded Tage Kemp in his Copenhagen 'Institute of Hereditary Biology' after Kemp had died while still in post. Mohr brought to the Institute his experience in blood group genetics, acquired at Lionel Penrose's Galton Laboratory in London, having earlier spent a year there, following a year in mouse genetics with LC Dunn at Columbia University.

Mohr built up the Copenhagen Institute into a major and comprehensive research centre, making a series of notable achievements in human gene mapping, including mapping of the cystic fibrosis locus (Eiberg et al., 1995) ${ }^{7}$ now often mistakenly attributed to DNA techniques. In this he was greatly helped by having the exceptionally able and practical Hans Eiberg to run his genetic marker laboratory, developing both a series of protein markers and then molecular techniques. As Mohr said in the interview:

'The real reason I hired him, I think, was that he was so clever at making orchids sprout.'

I was able to interview Hans Eiberg subsequently [95], who confirmed the symbiotic nature of their work together. Eiberg, who had begun his career as a laboratory technician, had the invaluable practical skills and ingenuity, whereas Mohr contributed the broad ideas (Figure 2). Eiberg also emphasises their warm personal relationship, something to be set against the difficulties that Mohr had with some other colleagues.

At this point I must return to Jan Mohr's predecessor, Tage Kemp (1896-1964), who can truly be considered the founder of Danish human genetics, his unit dating from 1935 and set up with support from the Rockefeller Foundation, which had already developed a farsighted (though ill-fated in the light of the impending war) policy of funding promising workers in human genetics across Europe. Kemp's work was strongly focused on hereditary disorders and he encouraged a series of young clinicians in a wide range of specialties to undertake genetic studies of disorders in their own field. The resulting theses were published as a remarkable series of monographs, 'Contributions from the University Institute for Human Genetics, Copenhagen', amounting to 42 in total, with a summary of the volumes published up to 1948. Along with Julia Bell's earlier 'Treasury of Human Inheritance' volumes ${ }^{8}$ (Bell 1922-1958) and the American studies of Madge Macklin on hereditary eye diseases and cancers (eg, Macklin), ${ }^{9}$ these early studies, continued in the case of the Danish series into the 1960s and succeeded by the journal Clinical Genetics founded by 
Mohr, with Scandinavian co-editors Kåre Berg and Arvid Böök, can be considered as part of the beginnings of medical as well as of human genetics.

Some of Kemp's views now seem uncomfortably close to eugenics, but after the end of the war his institute was seen as the one most suitable to host the first International Congress of Human Genetics, held in Copenhagen in 1956, opportunely just after the recognition by Tjio and Levan, based in nearby Lund, of the correct human chromosome number (Tjio and Levan), ${ }^{10}$ and allowing Tjio to present this as an exhibit. Jan Mohr, working with Kemp at the time, remembered the extensive work involved with this congress as a painful experience, and specifically cited it as a strong reason for making sure that a comparable burden would not be repeated when the new ESHG was founded a decade later, as recounted in my article on this subject (Harper). ${ }^{5}$

The records of the Copenhagen Institute under both Tage Kemp and Jan Mohr have been comprehensively archived and made part of the Danish National Archive; they are currently located in the Institute's present home, the Panum Institute, and have been used both by Danish historian Lene Koch, and by myself in relation to the beginnings of ESHG, but they deserve much greater study. At the time of my first visit, the Archive was deteriorating seriously, but fortunately remedial work by archivist Erik Kann from the Danish National Archives has ensured that it should be secure for the future.

Of course Jan Mohr and Tage Kemp were not the only important founders of human and medical genetics in Denmark; cytogenetics, especially its service aspects, was pioneered by Margareta Mikkelsen, who sadly died before I was able to arrange an interview, whereas there are others, in Copenhagen and elsewhere, whose memories deserve to be put on record, including Bengt Harvald and Mogens Hauge who created a Danish twin register in 1954, which continues to be productive to the present day. My third Danish interview, though, with ophthalmologist Mette Warburg [17], was an unusual one; it gives a valuable account of the work that a genetically orientated clinical specialist can achieve, in her case the area of malformation syndromes associated with eye defects. Ophthalmologists across Europe have indeed played a particularly important role in early human genetics, including Waardenburg from Netherlands, François from Belgium, and Franchescetti and Klein from Switzerland. The interview also documents the prejudices and difficulties facing women in academic medicine at the time, hopefully something that has now disappeared, at least in its most extreme aspects, from most of Europe.

\footnotetext{
Norway

The post-war history of human genetics in Norway has been closely linked with that of Denmark, due largely to the fact that Jan Mohr, brought up and trained medically in Oslo, spent a further 10 years there building up a human genetics unit, after his initial time in Copenhagen. However, delays in creating a full Chair in Oslo resulted in Mohr accepting the offer to succeed Kemp in Copenhagen, and though Oslo at once promised him what had previously been delayed, it was too late.

The upshot was that in 1967 the Oslo Chair was offered to Mohr's colleague and close friend Kåre Berg, at the time working in New York with Alexander Bearn. Berg remained head of this department and the dominant figure in Norwegian human genetics for the next 35 years; I interviewed him in Oslo in 2005 [49], on the same day as Jan Mohr, and it was fortunate that I did so, as he died not long afterwards, as also did Mohr, showing how unwise it is to put off opportunities for making recorded interviews.
}

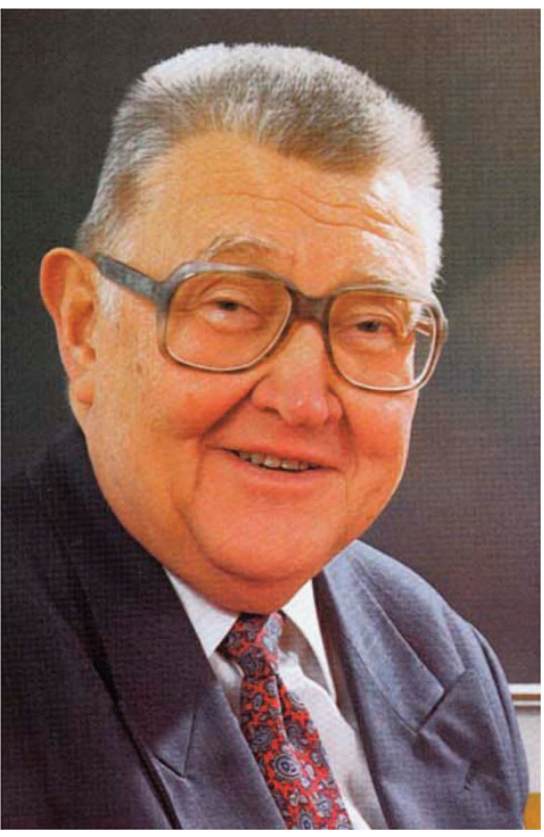

Figure 3 Kåre Berg Oslo (1932-2009).

Kåre Berg (Figure 3), like many others that I interviewed who had built up their units from the starting point of a single person, was clearly finding retirement difficult and that it was hard to adjust to no longer being the key individual for his country in the rapidly expanding area of human, especially medical genetics, as it moved to a more multi-centred structure. On the other hand, his interview describes how he was able to develop valuable political and other links which helped the specialty to evolve rapidly, something that is probably easier to achieve in a small country. It is notable that Norway was the first European country to formally recognise medical genetics as a full clinical specialty.

Berg's own special field was the genetics of lipoproteins and coronary heart disease, but his unit progressively broadened its base, with cytogenetics and associated genetic counselling developed early by Anton Brogge and Carl-Birger van der Hansen, who I was also able to interview jointly [50] and who gave me valuable information about the earliest years of Norwegian genetics. More recently, two key clinical geneticists in Oslo, Karen Ørstavik and Arvid Heiberg, have been interviewed by Dr Trine Prescott, as part of the new ESHG supported interview series.

The pre-war years in Norway were indeed unusual ones. The founder of Norwegian human genetics was Otto Lous Mohr, uncle of Jan Mohr, who was medically qualified, but had also trained in classical genetics with Thomas Hunt Morgan and Alfred Sturtevant at Columbia University in the 1920s. Mohr returned to Oslo as Professor of Anatomy and wrote a valuable early book for physicians, Heredity and Disease (Mohr OL), ${ }^{11}$ but never built up a human genetics unit himself, though he helped others with the genetic aspects of diseases that they had discovered (such as Fölling with phenylketonuria).

In the 1930s Mohr and other Norwegian geneticists were faced with political pressure to allow eugenicists, notably Jon Alfred Mjoen, to represent Norwegian genetics internationally, but they joined ranks to successfully oppose this. After the Nazi invasion of 1940 Mohr and a number of others were imprisoned and the university system was largely closed. 
a

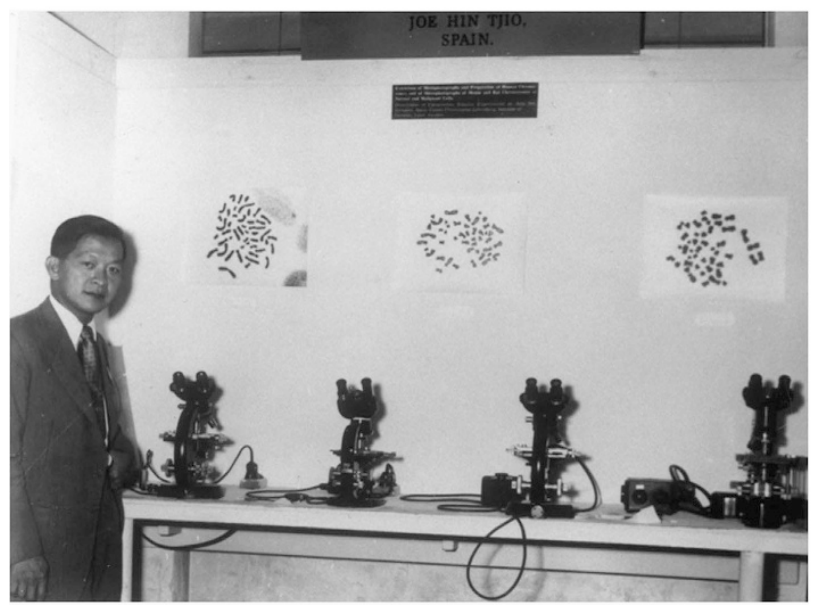

b

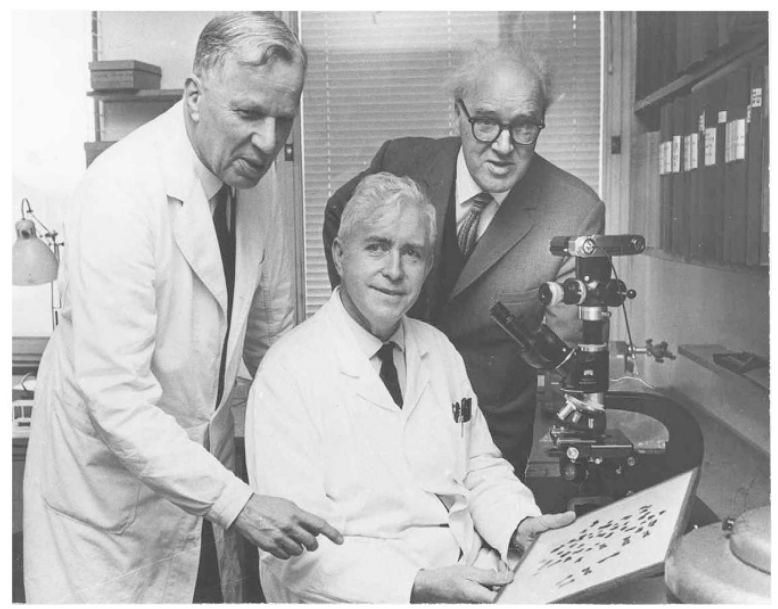

Figure 4 (a) Joe Hin Tjio (1919-2001) demonstrating the normal human chromosome number at the first International Congress of Human Genetics, Copenhagen, in 1956. Photo courtesy of Victor McKusick. (b) Albert Levan (1905-1998) (seated) with Lund colleagues; courtesy of Reinards Hochberg, University of Lund.

A marked incident reflecting these tensions resulted from the fact that Lancelot Hogben, a key figure then in British genetics, was at the time visiting Oslo to lecture; the morning after his lecture he was being driven to the airport to return to London when they met Nazi troops driving towards the city, the initial forces of the invasion. They at once headed for the Swedish by a remote road, from where Hogben was able to cross safely into neutral Sweden. Once there he made a base with his friend Gunnar Dahlberg in Uppsala, equally opposed to eugenics, but was only able to return to Britain by the somewhat circuitous route of Russia, the Trans-Siberian railway and North America, eventually reaching Britain some three years later (Hogben). ${ }^{12}$ Incidents like these (and many worse) need to be taken into account when charting the post-war development of European human genetics, as they illustrate how research, personal contacts and most of the scientific infrastructure across the continent were destroyed by the war and its aftermath, apart from a few geographical and political islands such as Britain and Sweden, to which I now turn.

\section{Sweden}

Sweden, with its considerably larger population than other Scandinavian countries, strong industrial base and its World War 2 neutrality, was an early pioneer in basic genetics, and during the 1930s had developed strong agricultural institutes such as that at Svaløf, near Lund in Southern Sweden, which were pioneering new techniques in plant cytogenetics. It is not surprising that Lund University, the closest academic centre to Svaløf, was also prominent in genetics and that it should have been the place where the human chromosome number should have been correctly determined in the closing days of 1955 (Tjio and Levan). ${ }^{10}$ My first visit there to document the early history of human genetics was in 2004, courtesy of the Mendelian Society of Lund, and although I did not at this time attempt to make any recorded interviews, I was able to meet a number of the key early workers, though the two key protagonists of the 1956 discovery, Albert Levan (1905-1998) and Joe Hin Tjio (1919-2001), were no longer living.

Levan was originally a plant cytogeneticist at Svaløf, but moved to the Lund Institute of Genetics to lead a small unit focused on cancer cell chromosomes. He developed strong links with American cancer centres and visiting workers to Lund included Joe Hin Tjio, Originally from Indonesia but later based in Spain, who had considerable technical expertise, including photomicrography (Levan himself preferred to draw chromosomes). Levan's work on cancer cells emphasised the need for an accurate determination of the normal human chromosome number and it was his collaboration with Tjio that provided the successful and unexpected resolution to this (Figure 4).

The discovery that the human diploid chromosome number was 46, rather than 48 as had been believed for the previous 30 years, has been written about previously, by myself and others (Hulten, ${ }^{13}$ Harper $^{2}$ ), but 50 years later the subject was still a sensitive one when I visited Lund, owing to the controversies concerning priority between Tjio and Levan, and I found that it had been largely a 'taboo' subject despite both protagonists being no longer living. In this situation being a foreigner, not a cytogeneticist, and largely ignorant of the local situation, was a great advantage, encouraging free discussion that might not have been possible otherwise. In fact this was something that I experienced repeatedly throughout the interview series - not that I would advocate ignorance as a virtue in the interviewing process!

The unexpected finding that resulted from my visit was that the 46 chromosome number might in fact have been discovered almost 2 years earlier, by the wife and husband team, Eva and Yngve Melander, also working on chromosomes in the Lund Institute of Genetics. Their work is very briefly mentioned in the 1956 Tjio and Levan ${ }^{10}$ paper, and I was able to meet them both at the residential home where they were then living. I have two main memories, one irrelevant but the other highly relevant, of this visit. The irrelevant one is that, when my host, Ulf Kristoffersson and I arrived at lunchtime, the residents were all enjoying a gargantuan meal, including a flat-fish whose diameter exceeded that of the plate - I made a mental note that Sweden must be a good place to grow old! The highly relevant memory was that, when we were leaving after our discussions, Eva Melander rummaged in her handbag and presented me with a photograph of chromosomes, on the back of which was inscribed: '46 XY human chromosomes; May 1954'. To my knowledge, no one, at least no one then living, had been shown this before, and my host nearly fell through the floor in astonishment.

Eva Melander was definite that her results had been shared with Albert Levan, but her own studies were terminated because she was unable to find the 'missing' chromosomes; when I asked her why she had not published the findings, she replied that they were not considered to be convincing until after Tjio's later work confirmed 
them, and that their quality was inferior to his - undeniable but sad nonetheless. I felt happy that I was able to use the photograph in my book 'First Years of Human Chromosomes' (Harper), ${ }^{2}$ albeit more than 50 years later.

Albert Levan (Figure 4b) continued working on cancer chromosomes for the rest of his life, and this theme has remained an important one for Lund up to the present through the work of Felix Mitelman, who I was able to interview considerably later [92]. His story is a remarkable one, beginning in the Arctic North of Sweden, where his parents had gone to work as dentists after leaving post-war Poland. Studying initially at Uppsala and then Lund, he began to work on cancer cells early, first as a pathologist but then more clinically, being appointed as head of a new medical genetics department, though as he notes in the interview, one without staff, labs, offices or anything else. (Actually most of the early medical genetics departments across Europe started like this, perhaps a testimony to our ingenuity and persistence as a group where funding issues are concerned!)

Mitelman's great contribution, in addition to his own studies, has been his success in bringing together the growing body of work on cancer chromosomes, through international workshops and his 'cancer chromosome database' (Mitelman). ${ }^{14} \mathrm{He}$ was able to help this evolve into the molecular era with identification of specific cancerrelated genes, which gave a biological basis to the previously confusing plethora of chromosomal changes found by early workers. Increasingly this work is resulting not only in more specific diagnosis but also in targeted treatments.

The area of clinical genetics and genetic counselling in Sweden, whether in Lund or other centres, has until recently taken a subsidiary place to more basic human genetic research, and has only recently become strong in its own right. Possibly this is due to the longstanding prominence of the country in design and the development of machines? Certainly Stockholm provides a good example of this in the person of Torbjorn Caspersson (1910-1997), who made significant advances in the chemical properties of nucleic acids from the 1930s, and who according to his former colleagues Lore Zech and Jan Lindsten, was completely fixated with machines, but not at all interested in the biological significance of what was being measured.

Caspersson seems to have been a difficult person to collaborate with, and even more so as a colleague, yet kind and helpful to any of his staff with personal difficulties. My interview with Lore Zech (19232013) [28] gives a frank assessment of his character; as I often found in the series, her situation was not made easier by her being a woman. Things were not helped for Caspersson's colleagues by his insistence on more than two authors on all papers and on alphabetical order, so that all publications ended up as 'Caspersson et al' regardless of his degree of involvement in the work. Anecdotes still persist in Stockholm about the empty chair left for 'et al' at a formal dinner!

The discovery of chromosome banding resulting from quinacrine mustard fluorescence (Caspersson et al) ${ }^{15}$ is the work best known to human geneticists as being associated with Caspersson and Zech (Figure 5), yet according to Lore Zech, Caspersson was not only not involved in the work but for a considerable time refused to believe it. As with Levan's work it had a botanical origin, but was soon recognised to be universal. Zech considered her most important contribution was for banding to allow specific identification of the human Y chromosome.

Caspersson's unit was based at Stockholm's Karolinska Institute, but clinical cytogenetics and wider medical genetics were developed at the nearby Karolinska Hospital, where Jan Lindsten, who I was also able to interview [27], had set up a group, which for a time also contained Maj Hulten, later in Birmingham UK, where I was able to interview

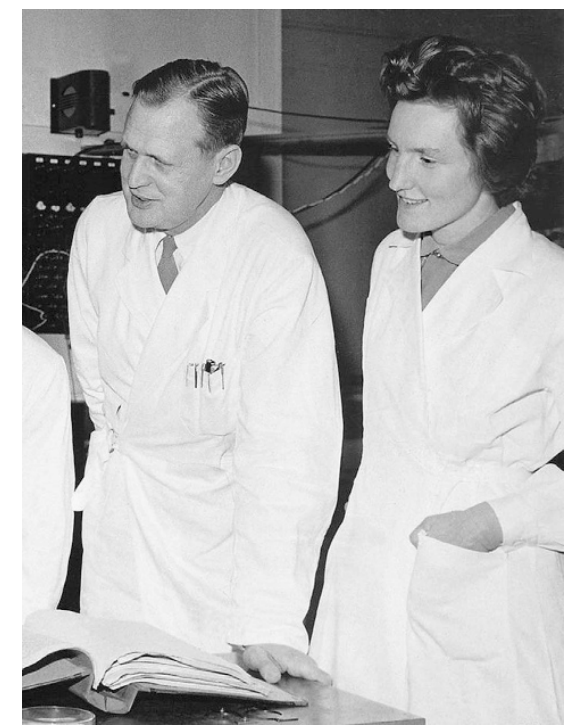

Figure 5 Torbjorn Caspersson (1910-1997) and Lore Zech (1923-2013), Stockholm. (Courtesy Lore Zech).

her too [10]. Lindsten had begun his genetics work while a medical student in Uppsala, where he worked closely with Marco Fraccaro, from Pavia, Italy [09], at the time of discovery of the first human chromosome abnormalities.

Uppsala had been prominent in genetics from an earlier time, too, in the 1930s, and reflected the considerable tensions then between genetics and eugenics. Eugenicist Herman Lundborg had set up a 'race biology' unit based on German ideas, but was succeeded by strongly anti-eugenics population geneticist Gunnar Dahlberg, who as we have seen earlier, gave refuge to Lancelot Hogben after the German invasion of Norway. Pressures were strong in Sweden, fearful for its neutrality, to follow Nazi ideology, and some kind of uneasy co-existence seems to have resulted. By the time that Fraccaro and Lindsten were in Uppsala, around 1960, the institute was headed by Jan-Arvid Böök, but his serious health and other problems led them to leave, to set up their own units in Pavia and Stockholm respectively.

\section{Finland}

From the viewpoint of my interview series, Finland is characterised by lost opportunities, as I failed to interview two of the three key people in Finnish human genetics. The first of these, Reijo Norio, I can give no excuse for, except that on my visits to Finland I was not trying to undertake interviews; fortunately he has since been interviewed by Finnish colleagues. Norio was responsible for developing the first and principal genetic counselling centre in Finland, based at an independent charitable foundation in Helsinki, Vaestoliitto. He also made the first detailed clinical and geographical documentation of the heterogeneous group of recessively inherited disorders known collectively as the 'Finnish disease heritage' (Norio), ${ }^{16}$ the genes for which were later isolated by Albert de la Chapelle and his colleagues and their prevention led by Leena Peltonen, whose early death prevented me from interviewing her. My interviewing was thus confined to Albert de la Chapelle (Figure 6), now living and still working in America.

His interview [84] yet again gives a vivid account of childhood in wartime Finland, though he was fortunate in his family escaping direct losses. His entry into genetics was through adult medicine, endocrinology and the sex chromosome disorders, leading him to cytogenetics and then to molecular research to identify the sex-determining gene 


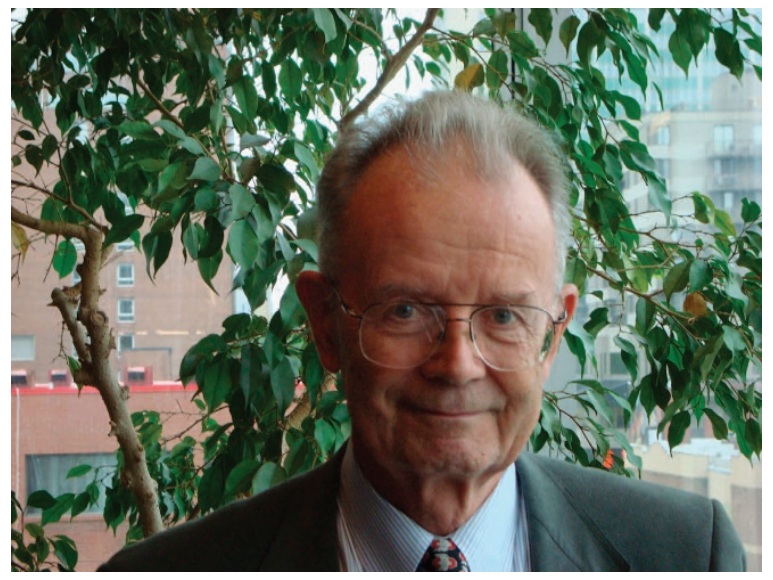

Figure 6 Albert de la Chapelle, Helsinki (Born 1933).

on the $\mathrm{Y}$ chromosome. Having lost the race to find this (see also the interview with Peter Goodfellow [98]), he turned to the task of mapping and isolating the Finnish disease heritage genes, the first of which was that for diastrophic dysplasia. His approach was to have a team of three workers for each disease, a graduate scientist, a clinical Fellow and himself.

By now his institute in Helsinki had become a major centre - he had been appointed to the Chair of Human Genetics there back in 1974 - and he turned to cancer genetics, mapping the first gene for Lynch syndrome before moving to Ohio to continue his cancer genetics research.

As a postscript to Scandinavian human genetics I need to say a word about eugenics in these countries. I have already mentioned the tensions involved in the pre-war and wartime years, but in contrast to most of Europe, many of the ideas, largely shorn of their previous coercive nature and Nazi associations, were quietly introduced into post-war social and medical developments, such as the legalisation of sterilisation and pregnancy termination, under left wing social democratic governments. This caused a major public furore when it became widely known, but in fact they had been implemented largely for the benefit of those involved and reflected pragmatic policies rather than ideology. This is well discussed in a book by Broberg et al, ${ }^{17}$ which makes salutary reading when, as is now the case, 'eugenics' is a pejorative term and one often used with widely differing meanings.

\section{Netherlands}

I was able to interview five workers from the Netherlands, an inadequate number for a country which, though small, has contributed disproportionately for its size to European human genetics. Those that I did see, though, gave me a large amount of information on the overall development of the field, not just their own work.

Lou Went of Leiden, aged 92 at the time of my visit, was the oldest person in my interview series [79], whereas Hans Galjaard (Figure 7), based in Rotterdam [76], had been the pivotal person in promoting the development of medical genetics services across the country, in addition to his own outstanding work on inherited metabolic disorders and their prenatal diagnosis.

Initially human genetics in the early post-war period seems to have developed partly around cytogenetics and radiation genetics, in units such as that of $\mathrm{G}$ Anders (Groeningen), but also with the help of a number of imported scientists appointed to Chairs, notably in Leiden, such as Marco Siniscalco from Italy and Martin Bobrow and Peter Pearson from the United Kingdom. A number of outstanding clinical

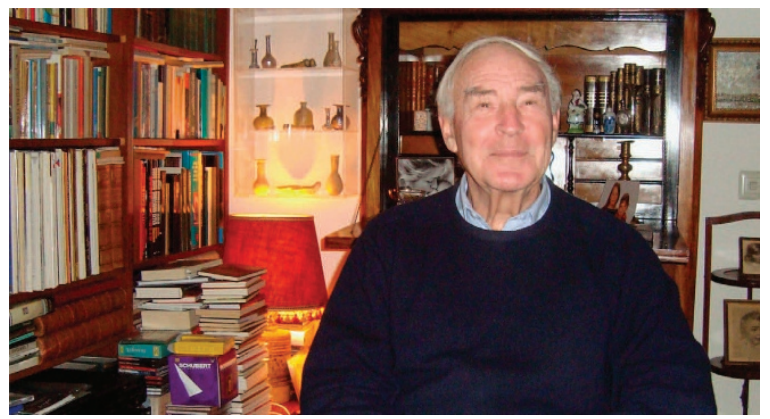

Figure 7 Hans Galjaard, Rotterdam (Born 1935).

specialists were also strongly interested in genetics, such as Petrus Waardenburg (inherited eye disease), neurologist George Bruyn (Huntington's disease) and Jaap Bethlem (muscular dystrophies), giving strong foundations for later developments in the molecular genetics of these fields.

One of Hans Galjaard's notable achievements was to work closely with the health insurance system leaders to convince them of the value of medical genetics and to encourage them to promote its development in the different medical academic centres across the country. This proved especially valuable when human molecular genetics arrived, with a carefully planned system of sharing responsibility for different major disorders, linked to research in the particular field and ensuring that high quality services and research were spread across the country and wasteful duplication avoided.

Galjaard also proved to be a charismatic communicator of genetics, and of science in general, to the general public, both on television and by his writing, something that greatly benefited human genetics, but earned him the disapproval of a number of 'serious' Netherlands scientists. When I left Hans Galjaard he was busy organising an exhibition for the public on the theme of 'Science and Beauty', his enthusiasm for communication with people at large undiminished.

In Leiden I was able to interview two workers who have made major contributions to human molecular genetics, in particular to Duchenne muscular dystrophy. In a good example of the symbiotic approach, GertJan van Omenn [78] focused on the basic molecular research aspects, whereas his colleague Bert Bakker [77] developed molecular genetic diagnostic services, primarily for Duchenne muscular dystrophy but serving as a model for broader molecular genetics applications worldwide, and especially across Europe. Some of these contributions appear in two 'Witness Seminar' publications on Human Molecular Genetics in Medicine and Human Gene Mapping (Jones and Tansey $\left.{ }^{18,19}\right)$. My other Netherlands interview was with Han Brunner, of Nijmegen [99], who illustrates how valuable the research of a broadly based and scientifically orientated clinical geneticist can be in forming a bridge between basic scientists and clinicians in human genetics.

Overall, I was struck by the value of the pragmatic Dutch approach to human genetics, both in research and in health service applications, and most of all by the importance of forging close links with those actually responsible for funding and implementing major innovations, who themselves also seem in The Netherlands to have been a far-sighted group of people, providing they were approached in a way that they could understand. There is a lot that everyone can still learn from this example.

\section{Belgium}

With its linguistic divide, Belgium is not an easy country to assess, at least for an outsider. 
My interviewing experience has been entirely confined to Dutchspeaking Flanders, and within this to Leuven, which is the major integrated human genetics centre, and with which I already had close professional links.

Nevertheless, French-speaking Belgium can undoubtedly provide one of the earliest pioneers of human cytogenetics in the person of Hans de Winiwarter, whose studies came closest of any early worker to identifying the correct human chromosome number in 1912 (Winiwarter). ${ }^{20}$ His estimate of 47 chromosomes may have been influenced by the fact that he did not accept the existence of a human Y chromosome, but he very wisely concluded that the technical limitations of the time meant that one could not decide on an exact number; if other later workers had been as cautious, the erroneous estimate of 48 would probably not have become entrenched for over 30 years.

Another early contributor to human cytogenetics was Frans Janssens, based in Leuven, who identified chiasmata at meiosis and recognised their role in crossing-over. And it was in Leuven that Herman vanden Berghe (Figure 8), who died very recently in January 2017, was able to develop medical genetics from the 1960s, having a major role in creating a network of centres across the country.

Vanden Berghe [66], like many of the founding medical geneticists, was medically trained but strongly scientifically orientated. He was based initially in cancer research and cell culture, extending this to cytogenetics in the early 1960s, and building up different areas of medical genetics research by sending young colleagues to American centres for post-doctoral research. From this solid base, and from close contacts with government ministers and the health insurance system, he was able, like Galjaard in Netherlands, to facilitate prenatal diagnosis (not easy in a mainly Catholic country), and to see health service funding provided to develop genetic services in a strictly limited number of academic centres on a geographical basis. His approach to this must have required a forceful personality to overcome the rivalries between groups of workers:

'Formally for clinical genetics no centre dates back earlier than 1974 because actually on behalf of the minister I went around the country

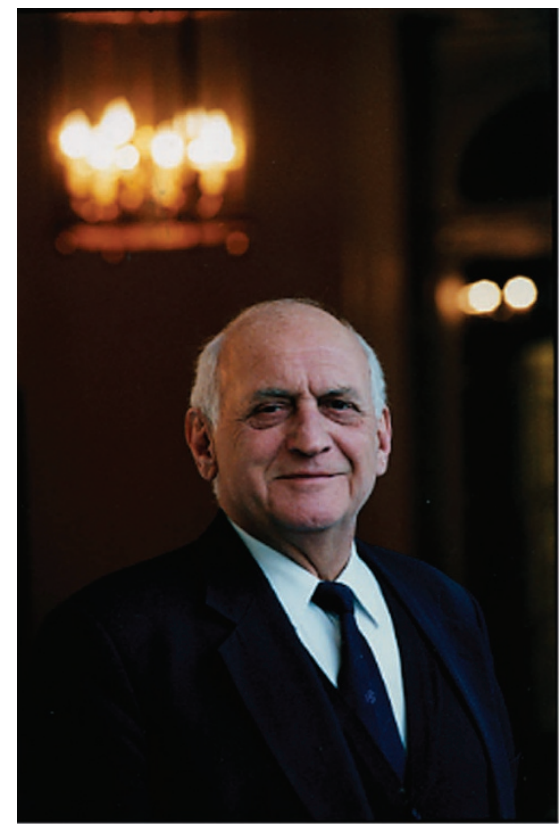

Figure 8 Herman vanden Berghe, Leuven (1933-2017). and founded these centres; brought people together. In Liège for example there were 3 candidates. We gathered in a café and I told them there would be one lab which would be funded. Now you can go out and shoot each other and I will see who comes back or you can agree. And they agreed to work together.'

Vanden Berghe's 'second generation' of workers, including JeanJacques Cassiman, Gerry Evers Kiebooms and Jean-Pierre Fryns (the last of whom I interviewed [65]) were a talented group of people, who ensured that the greatly enlarged Leuven Institute continued to flourish after its founder's (reluctant) retirement. Now this entire second generation has also retired, showing the importance of documenting these early developments as fully as possible while there is still time.

I cannot leave Herman Vanden Berghe without mentioning his special interest - the French hunting horn! His interview describes how he developed a lifelong passion for this unusual instrument, and he later sent me a CD of his group performing music for it (now deposited in the archive of the interviews project), another illustration of the multifaceted talent of so many of these pioneers.

Inevitably this account is biased towards Leuven and ignores other important units in Belgium where I was unable to make interviews. As I have already noted, a full and accurate picture can only be obtained by each country undertaking a series of interviews with its own key workers, and by preservation of the relevant written history. Fortunately, such a programme is now beginning for Belgium.

\section{Germany}

Much has already been written about eugenics in Germany under the Third Reich, and about how many eminent German geneticists were either complicit or directly involved with the abuse and atrocities. More recently, historians are starting to study post-war genetics, whereas the special problems of communist East Germany are also receiving attention. Knowing this, I realised that I could not possibly undertake a major study with any validity; in fact I had initially decided to omit Germany from my interview series entirely, but by good fortune I was informed at the end of 2003 by my friend and colleague David Cooper that his predecessor as editor of the journal Human Genetics (originally Humangenetik), Friedrich Vogel (Figure 9), was seriously ill but would be happy to see me.

So I travelled to Heidelberg without delay and fortunately found him much improved. The resulting interview [05], although inevitably subjective, provided what I think are some valuable insights into the post-war development of German human genetics, of which I give a few here.

Vogel had been captured as a young soldier on the Russian front, but was fortunate in being released early, rather than only after several years or never, like so many others. After medical studies in Berlin he decided to study genetics, having concluded that his initial preference, psychiatry, had insufficient scientific basis. (Interestingly a number of other early human geneticists who I interviewed also had psychiatry as their original field of interest).

Vogel went to study with Hans Nachtsheim, primarily a plant geneticist, but also with dubious connections with the previous regime. He wisely advised Vogel to study human mutation, now a favoured topic on account of radiation concerns, with the result that in now classical work he studied the mutation rate in retinoblastoma (Vogel). ${ }^{21}$ Vogel was able to establish links at the 1956 Copenhagen congress with James Neel and also with Arno Motulsky, of Seattle, who became a lifelong friend and collaborator. Their joint book, 


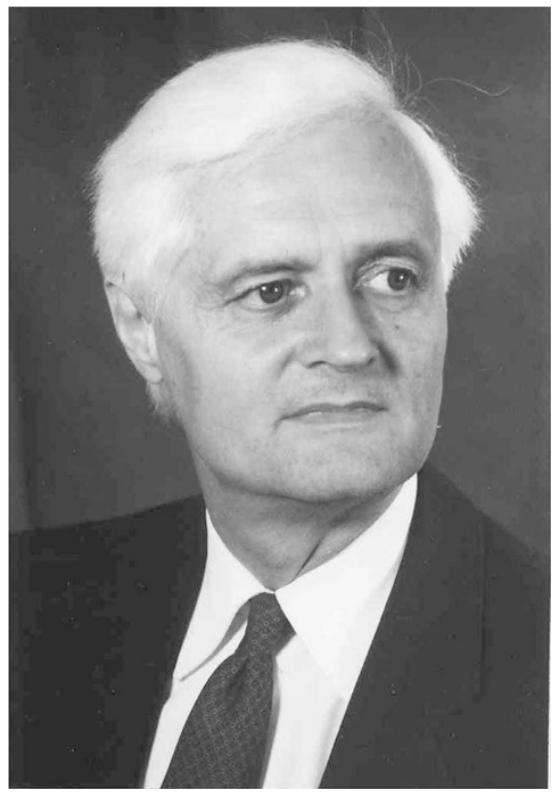

Figure 9 Friedrich Vogel, Heidelberg (1925-2006).

Human Genetics, Problems and Approaches (Vogel and Motulsky), ${ }^{22}$ rapidly became the benchmark textbook for the field internationally.

Meanwhile, the (West) German government had decided to establish a series of Human Genetics institutes, and Vogel, still young, was appointed to the new Chair at Heidelberg, despite manoeuvring by the still influential network of older formerly Nazi scientists. Vogel was also asked by Springer publishers to start an entirely new journal, Humangenetik, (now Human Genetics), with Arno Motulsky as coeditor. This combination of activities allowed Vogel to have a key role in bringing Germany back into the mainstream of European human genetics after a long period in the wilderness.

A further landmark directly involving Vogel was the organising of the 1986 International Human Genetics Congress in Berlin, giving the opportunity of re-establishing links with East Germany. Vogel's contacts in the then divided city put him in a good position to negotiate for attendance of those in the East.

It is important that the considerable number of early human geneticists still living from both West and East Germany are interviewed soon, so that a fuller picture can be obtained from different angles. I have also not seen a detailed account of the split that led to a new Human Genetics Society, free from the lingering influence of the previous generation. Fortunately, a number of younger German historians are beginning to study these aspects.

\section{Russia}

The history of Russian human genetics is a tragic one; although some of those currently in the field are prominent internationally in research and are attempting to develop genetic services comparable to those found over most of Europe, the shadow of events beginning over 80 years ago still hangs heavily over the field. In the 1930s, the country was a world leader in general and human genetics, but by the outbreak of World War 2 all of this research, and many of the people leading it, had been swept away, a process completed a decade later with the banning of all teaching of orthodox genetics, the destruction of textbooks and animal and plant research stocks, and even a denial of the existence of genes and of chromosomes as the basis of heredity.
Amazingly this bizarre situation lasted until the mid 1960s, well after the structure of DNA was known and chromosome abnormalities recognised as underlying some major genetic disorders. Workers tried to disguise their research by hiding it under more innocuous labels such as 'Paediatrics' or 'Microbiology', but essentially all areas of genetics were a 'taboo' subject. The only type of genetics allowed was that promoted by the fraudulent agronomist Lysenko, which had the inheritance of acquired characteristics as its defining feature and denied not only Mendelism but all classical genetics.

Although Lysenko was the person who ruthlessly enforced these views, they were directly promoted and supported by Stalin himself, and also by Nikita Kruschchev after Stalin's death. Inheritance of acquired characteristics suited Stalin both personally and politically, but as with all false science, it eventually collapsed under its own weight of contradictions, though not before it had caused immense and permanent damage to Russian biological sciences and resulted in the death of numerous workers in genetics. This disastrous saga, a major factor in the eventual downfall of Russian communism, has been much written about from the viewpoint of agriculture and general genetics (see Medvedev), ${ }^{23}$ but its equally profound effects on human and medical genetics have received relatively little attention.

I have had a longstanding interest in this topic for many years, since first reading the book by Zhores Medvedev 'The Rise and fall of TD Lysenko' (Medvedev). ${ }^{23}$ This was reinforced by the somewhat surreal experience of attending the 1978 International Genetics Congress in Moscow, by which time genetics had been partly rehabilitated but Lysenko's errors and crimes were still not admissable. It was not until after the fall of the Soviet Union that I was able to visit first St Petersburg, then Moscow, to try to find out more about the history of Russian human genetics and to make some recorded interviews. I shall here confine myself to these interviews, though I still hope to write a more detailed paper on the wider topic; a brief account is given as chapter 16 of my 'Short History of Medical Genetics' (Harper). ${ }^{24} \mathrm{I}$ must record here, though, that by 1936 Moscow had the first and certainly the largest Medical Genetics Institute in the world, with over 200 medical staff, advanced cytogenetic research and its own Journal. All of this was destroyed in 1937 on the orders of Stalin, while its Director, Solomon Levit, was executed, along with numerous other geneticists.

I was fortunate to be able to meet all three successive heads of the reconstituted Moscow Institute of Medical Genetics, Nikolai Bochkov, Vladimir Ivanov and Yevgeny Ginter (Figure 10), and to make full recordings with the first and third of these [46, 47]. These showed how difficult and painful the process of rehabilitation has been, with economic problems arising as soon as political ones had disappeared. They also illustrated the remarkable role of Nikolai TimofeefResovsky, one of the few survivors (literally) of the purge of Russian geneticists; he was primarily a Drosophila geneticist whose main later scientific contributions were in the area of radiation genetics and who had the distinction of at one point heading a unit whose entire staff, including himself, were political prisoners.

Bochkov, Ivanov and Ginter had all worked with TimofeefResovsky during the 1960s in Obninsk, not far from Moscow, giving a remarkable 'founder effect' for Russian human and medical genetics when it was finally resuscitated in the 1970s; the story of this as told by Bochkov in his interview is a fascinating one, both his humble origins and wartime struggle as a child working on the land, while his father was away in the army, and much later his summons home while on a travelling scholarship to American medical genetics centres, in order to create a new institute in Moscow. Equally compelling is the account of Zhores Medvedev (Figure 11), yet another co-worker of 
a

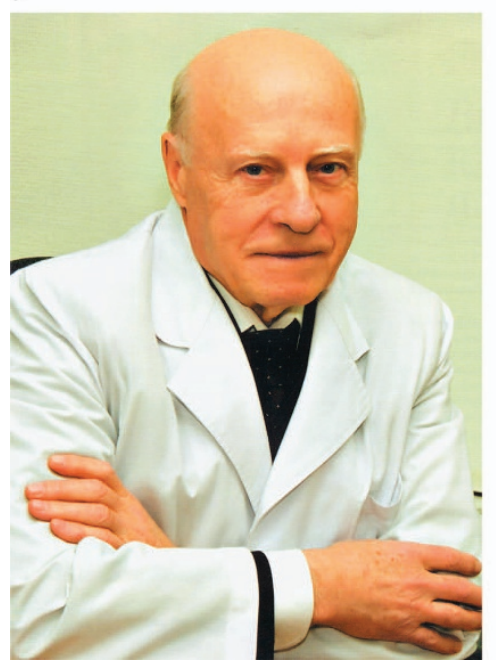

b

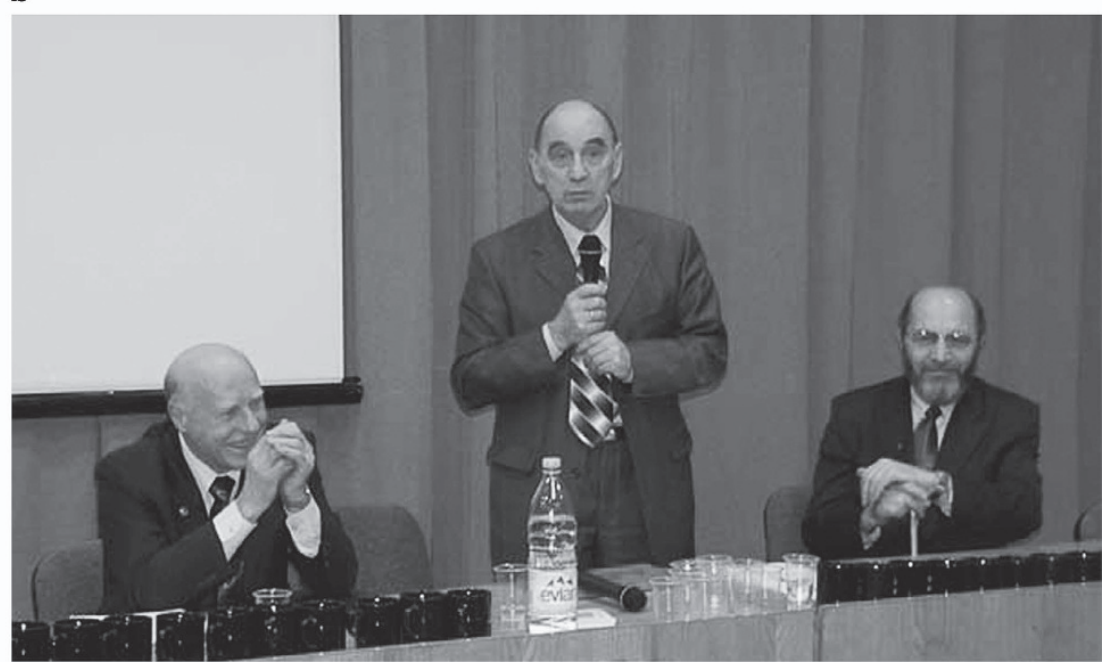

Figure 10 (a) Nikolai Bochkov, Moscow (Born 1931). Courtesy Nikolai Bochkov. (b) Nikolai Bochkov (L), with Vladimir Ivanov (R) and Yevgeny Ginter (centre), the three successive directors of the renewed Moscow Medical Genetics Institute. Courtesy European Society of Human Genetics.

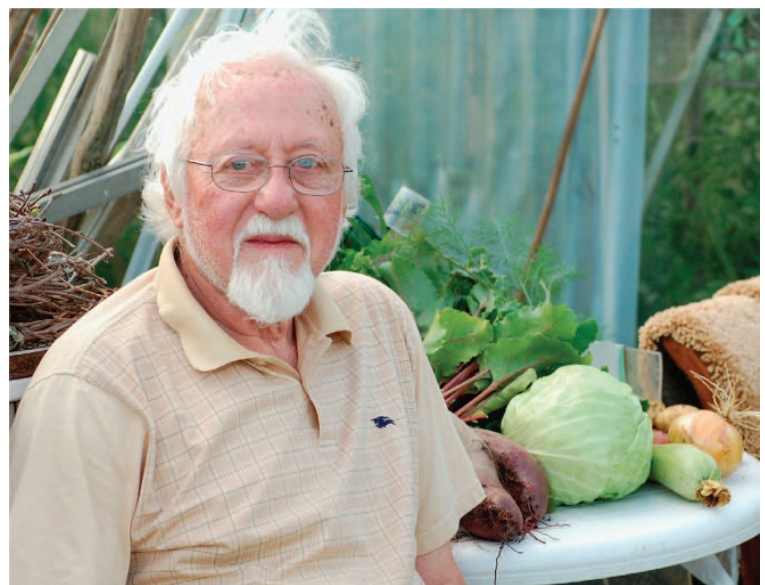

Figure 11 Zhores Medvedev (born 1925). Courtesy Zhores Medvedev.

Timofeef-Resovsky, expelled from Russia in 1972 after he had earlier been imprisoned in a psychiatric hospital for publishing his book on Lysenko in the West after it had been banned in Russia. His later interview with me in London [58] focused on how these upheavals had affected human genetics.

In St Petersburg, genetics had also been prominent in the early years before its suppression; indeed, confusingly for the outsider, senior workers often seem to have shuttled between Petersburg and Moscow, and even to have directed institutes in both cities at once. In the late 1960s human genetics was cautiously revived by cytogeneticist Aleksandra Prokovieva-Belgovskaya and medical genetics by neuropathologist Sergey Davidenkov, but official discouragement seems to have persisted. During my visit I was given considerable information on the Petersburg workers but have been unable to use it fully, as it is mostly in Russian.

Although my interviews and discussions in Moscow and St Petersburg vividly illustrated the tribulations of Russian genetics, an additional and unplanned interview [45] with Minsk (Belarus) pathologist Gordon Laziuk, who had also studied genetics with Bochkov, provided insights into the Chernobyl nuclear disaster.
Perhaps I may be allowed a word first, though, about the background to this. After my time in Moscow discussing and interviewing people on historical aspects of Russian genetics, I was invited to the 2005 five yearly all Russia Medical Genetics Congress, held in Ufa, in the foothills of the Ural mountains, several hundred kilometres northeast of Moscow. This event brings together human and medical geneticists from the far flung parts of the country, and includes the various 'former Soviet Union' countries, but is not strictly international, so that I was the only true 'foreigner' present. The meeting gave a unique opportunity to meet workers from many centres which I knew little about, and which I would never have been able to travel to. Ufa itself is a pleasant, prosperous and relaxed small city enjoying the economic benefits of oil in the region.

My interview with Gordon Laziuk, undertaken with the help of Moscow genome scientist Nikolai Yankowsky as translator (accounting for the variable use of the 'third person'), focused on the Chernobyl disaster; he was at that time running a congenital malformation register in Minsk, with data from several years before the disaster occurred in 1986, which covered the regions most affected by radiation. Unfortunately no one had any clear idea of the actual doses of radiation involved; these were only collected or made public outside Russia. Laziuk went immediately to the scene but found only confusion and chaos.

'PSH What was his personal impression being at the Chernobyl station so soon after. Did it make a very strong personal impression, the scene of this disaster?

GL That time was the most terrible for me. It was panic for all people around and we didn't know anything actually. We were not informed. We were not radiobiologists so it was a new situation. So, the maps were created in three years. At that time no maps about how it was. ------ So I was a member of the Government Commission for that, should have been the most informed, but I didn't know that, and ordinary people were not aware of anything.

PSH Was there panic among the ordinary people living there?

GL Yes, ordinary people were in panic. And practically all villages were visited by me personally. 
a

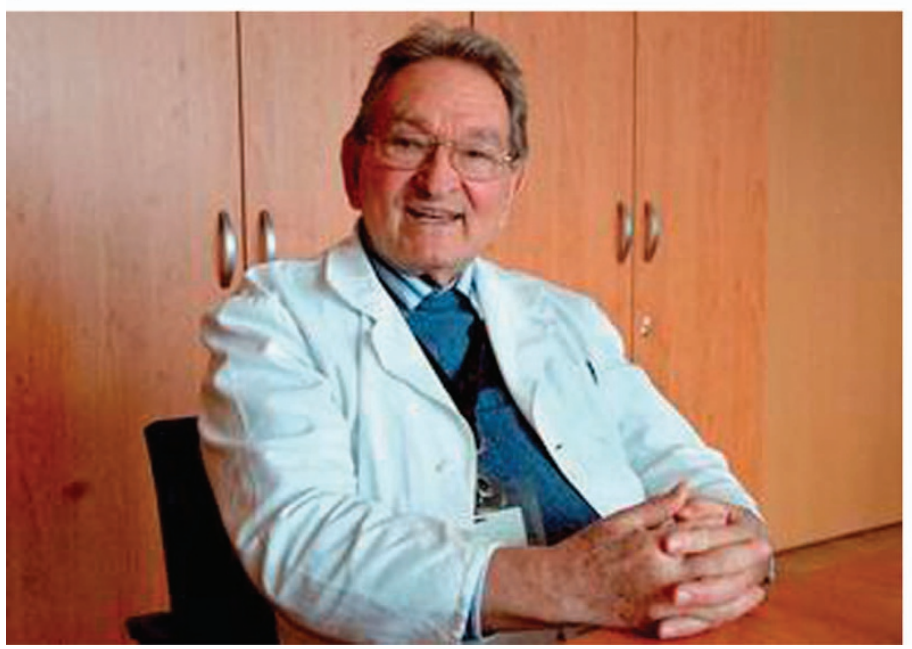

b

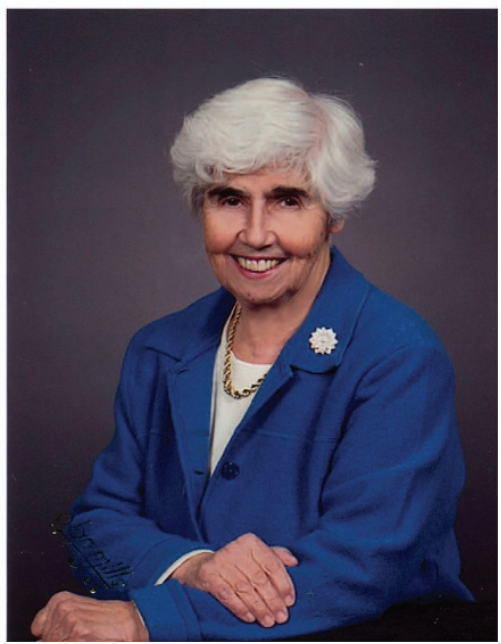

Figure 12 Human genetics in Czechoslovakia. (a) Milan Macek Sr, Prague, (born 1932); (b) Renata Laxova, Brno (born 1931).

PSH Has he ever written a personal, historical account of this time?

\section{GL It's the first time now!'}

Neither he nor other experts were allowed access to relevant data, and the official response was concentrated on denial and cover up; Yankovsky commented to me that at his own Moscow institute the only indication they had of something being wrong was when the police appeared and removed all Geiger counters from the building.

Ironically, this was not the first Russian nuclear disaster. In 1958, at the secret centre in the Urals developing atomic weapons, a massive explosion involving buried atomic waste resulted in radiation being carried by an ice storm for hundreds of kilometres, undetected internationally only because it remained within Russian boundaries. It was covered up not only in Russia but by Western secret agents and governments, and Medvedev unintentionally created a furore when after his expulsion from Russia he published a book on it in Britain (Medvedev), ${ }^{25}$ naively assuming it would be common public knowledge there.

To end this account of troubled times on a happier note, it was good to see how current research and the aspirations of those working in the field were now (2005) fully in the mainstream of European human and medical genetics. And as a visitor I benefited from their retention of what used to be a regular feature of most European meetings in the days when genetics was a small and more relaxed field - the post-congress tour. So the day after the end of the meeting three busloads of participants set out for the heart of the Ural mountains on a two day visit to stay in what used to be a 'young pioneer' camp, located most scenically beside a limestone river gorge. It was May and Spring was at its most beautiful, with the mixed woodland coming into leaf. I was able soon after we arrived to slip away in the dusk undetected by our helpful but eagle-eyed guide, and to enjoy sitting in the forest listening to a chorus of nightingales, nightjars and cuckoos all calling together, making me realise how much natural beauty we have lost in Britain and many other European countries.

\section{The Czech republic}

The Czech Republic and its predecessors saw the beginning of modern genetics with Mendel, and now are leading the way in systematically documenting the history of human genetics in their country, but it has been a difficult road in between. Soon after it had established itself as independent, Czechoslovakia, as it was then, was occupied by the
Nazis, engulfed in World War 2, and then forced to become part of the post-war Soviet empire, which entailed the acceptance of Lysenkoism, with the consequence that Mendel became reviled and mendelism officially unacceptable.

The ways in which this affected the various 'Eastern Bloc' European countries, already with established classical genetics and well developed international links, and how they dealt with the situation, is of considerable historical interest and is now receiving study. In terms of my interview series I can claim personal experience only for the Czech Republic, though others have done interviews recently for Hungary and former East Germany (none as yet have been published to my knowledge). A lively discussion session on the topic also occurred at the memorable Second International Workshop on Genetics, Medicine and History held in Mendel's abbey in Brno in 2005 (www.genmedhist.org/ workshops). I have been able to interview two Czech medical geneticists coming from very different perspectives; Milan Macek Sr (Figure 12a), from Prague [89] and Renata Laxova (Figure 12b) [55], originally from Brno but later working in Britain and then in Madison, Wisconsin; both paediatricians by background. They give accounts of early human genetics developments in their countries, diverging as they reach the troubled times of imposed Soviet communism and Lysenkoism.

Macek gives the 'insider's' viewpoint, trying to make the best of a system that was flawed yet had some valuable aspects in the way it advanced innovations and their applications in medicine. The state controlled system had definite advantages for the development of medical genetics once Lysenkoist ideology could be jettisoned in the mid 1960s; Mendel had now again become respectable, just in time for the 1965 centenary of his work. After the end of communism Macek found himself having to fight for the maintenance of these advances in the face of growing commercialisation of health care.

Renata Laxova's early life is given in full in an autobiography written primarily for her family (Laxova). ${ }^{26}$ Sent to Britain on the Kindertransport as a child, her resulting fluency in English proved to be a twoedged sword when she returned to Brno after the war, placing her under continuing suspicion as 'contaminated by the West' but allowing her to develop valuable links as a paediatrician interested in genetics, most notably with Lionel Penrose when he visited Brno for the Mendel centenary conference in 1965. Her vivid account of the Penrose family's hospitality and generosity, when she and her husband were later forced to flee the country after the 1968 Russian invasion, 
gives insight into both Penrose's character and into the close personal links that can develop in a small specialty such as medical genetics, where many of its members know each other across Europe and indeed the world. These links helped Renata Laxova greatly in reestablishing her career, first in London and then in Madison, Wisconsin.

\section{France}

France has a complex and at times unusual history in relation to human genetics, especially in its early years, though now it is at the forefront of mainstream medical genetics research and services. Fortunately, I was able to make a significant number of interviews (15 in total) thanks largely to the hospitality of Arnold Munnich and his colleagues at Hopital Necker, Paris, which I used as a base; I was also helped by being able to speak French, though this often meant that the interviews took place in a mixture of languages.

Genetics had a difficult start in France, with Mendelism slow to be accepted, as was the case with Natural Selection and Darwinism in the 19th century; Darwin was repeatedly rejected when proposed for the French Academy of Sciences, and there was persistent support for Lamarckian inheritance of acquired characteristics, even though Lamarck himself and his views had been largely ignored in his lifetime. The few supporters of mendelism, such as Lucien Cuénot in Nancy, gained few followers and genetics was little taught in the universities up to the 1950s.

The sudden emergence of genetics after World War 2 can partly be attributed to the remarkable group of molecular biologists in Paris, including Lwow, Jacob and Monod, whose links were mainly with American basic geneticists and who had little regard for human genetics. However a number of influential medical workers, notably paediatricians such as Robert Debré and Maurice Lamy in Paris, having seen the decline of infectious and nutritional causes of child mortality, realised that genetic conditions were the next major challenge, and that genetic research was essential if they were to be overcome.

Lamy (Figure 13) was no longer living when I began my interviews, but I was able to meet a number of his younger colleagues who developed various areas of human genetics, including Pierre

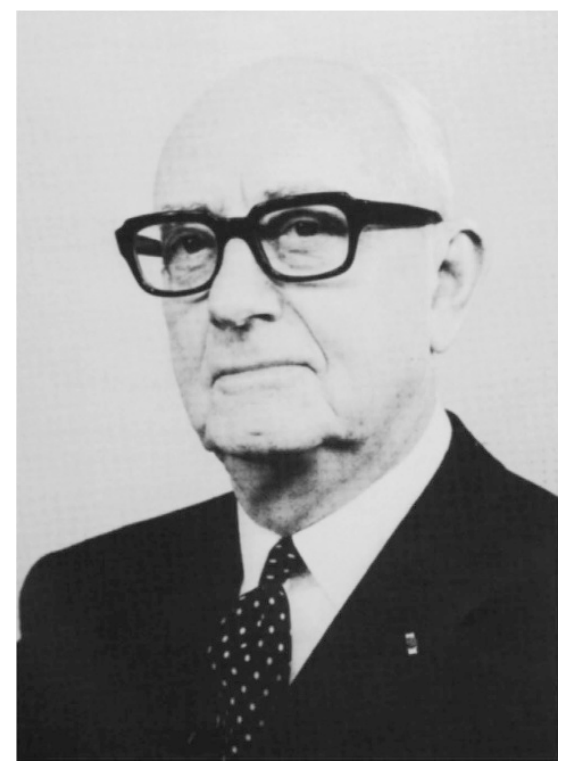

Figure 13 Maurice Lamy (1895-1975), pioneer of French medical genetics. Photo courtesy of Jean Frézal.
Maroteaux [36], (pioneer in bone dysplasias), Josué Feingold [35] (statistical genetics), Jean-Claude Kaplan [40] (biochemical genetics) and most notably Jean Frézal (human gene mapping). As I cannot possibly describe all of these interviews here, I shall simply give a background to my interview with Frézal [44] (Figure 14), who had emerged as successor to Lamy at Hopital Necker and as leader for the not entirely harmonious community of French medical geneticists.

This interview provides a good example of how a prospective interviewer may need to be persistent and opportunistic, as well as flexible, as the following background note, made at the time, indicates:

\section{INTERVIEW WITH PROFESSOR JEAN FRÉZAL. 22 APRIL 2005}

'This interview was undoubtedly the most important of the series undertaken in France, since Jean Frézal has been the pivotal figure in development of the field since the beginning. Obtaining the interview was full of unexpected problems, however.

It was originally planned to see him during my visit last year-indeed this was one of the main reasons for this. However, a few weeks before, he wrote that he had been advised to have coronary bypass surgery for angina, but that he had been assured that it was routine and he still hoped to see me.

Arriving in Paris last April I found everyone most distressed because he had developed serious infection postoperatively, was in intensive care and not expected to survive. He made a very gradual recovery however, and 6 months later was much improved.

The interview was thus top priority for the present visit, but three weeks beforehand he had another coronary attack, though mild, so an interview still seemed feasible. Then he was advised by his doctors to convalesce by the sea, so I found he was no longer in Paris during my visit, but at La Baule in Brittany.

Fortunately the excellent train service made it possible to travel to La Baule and back in a day. So I caught the 7:30 am train from Gare Montparnasse and was in La Baule by $11 \mathrm{am}$, after a journey through beautiful country on a glorious spring day. I decided to divide the interview into two sessions to avoid tiring him; the first deals mainly with his own work, the second with the wider development of medical genetics in France.

As well as the interview, he and his wife took me for an excellent lunch in La Baule, following which I was able to walk along the beach for an hour while he rested. Leaving La Baule at 7 pm on the TGV, I was back in Paris by 10:00 pm.'

Jean Frézal died 2 years later.

Around the same time as medical genetics was developing on a broad base at Necker, another paediatric based group was making major advances in cytogenetics at Hopital Trousseau, under Raymond Turpin, which led directly to the discovery of trisomy 21 as the basis for Down's syndrome. This discovery was until recently associated exclusively with the name of Jerome Lejeune, but his precise role remains uncertain and controversial up to the present day. What is clear is that the chromosome laboratory of Turpin's department was set up unaided by Marthe Gautier, who was largely excluded from credit for the discovery until very recently. The entire topic remains a highly sensitive one in France as a whole, and here I shall merely note that Marthe Gautier has herself written an account to which I added a commentary (Gautier and Harper). ${ }^{27}$ Here again is an example, all too frequent in my interview series, of the key contributions of able female scientists being ignored or downgraded by their male colleagues. 


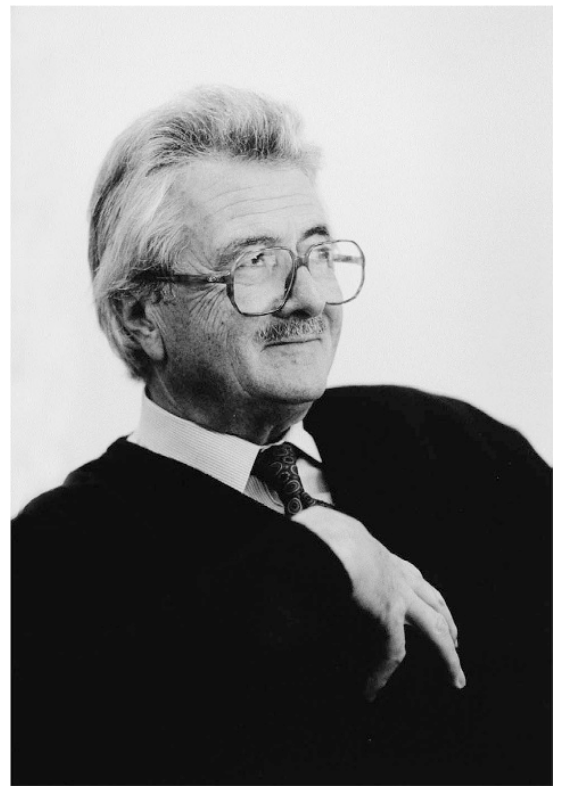

Figure 14 Jean Frézal (1922-2007), Paris. Courtesy of Jean Frézal.

Lejeune's important later role in French cytogenetics was an undeniable, if controversial one, and helped to make Paris a major centre for human cytogenetics, along with others such as Jean de Grouchy and Catherine Turleau [42], based at Necker, to which Lejeune later also moved. But Lejeune's autocratic and extreme Catholic views, (he sent a letter to all geneticists across France asking them to sign a guarantee that they would not be involved in prenatal diagnosis), caused a deep rift in French medical genetics and took Lejeune away from any direct role in the field. The interviews with some of Lejeune's former colleagues, such as Roland Berger [38], Marie-Odile Réthoré [37] and Marthe Gautier illustrate the conflicting views over Lejeune and his work.

Prenatal diagnosis was in fact developed early in France by a remarkable husband and wife team, André and Joelle Boué (Figure 15), neither now living, with whom I made a joint interview [43]. Their research was based in a separate institute founded by Robert Debré after he had retired from Hopital Necker, and thus was insulated from some of the rivalries of Paris human genetics. Initially, they provided a prenatal diagnostic service for most of France and the early history of this is documented in the transcript of a 'witness seminar' on the topic (Loewy 2010). Their account of their early years in Iran, developing cell culture techniques in relation to vaccines, is a fascinating one, and is given in more detail in a paper describing the beginnings of French cytogenetics by Simone Gilgenkrantz of Nancy (Gilgenkrantz and Rivera), ${ }^{28}$ who I was also able to interview [39].

My initial French interviews were all Paris based, not surprising in view of the centralised nature of French science until relatively recently, but I was keen to obtain a wider picture and to a limited extent was able to do this by interviewing two of the key workers from Marseille, Ségolène Aymé [85] and Jean-François Mattei [94]. Marseille was probably the first centre in the country to develop a comprehensive service-based medical genetics department, and its success was in part based on the strong political connections of Mattei and his colleague François Giraud, described below, as well as on the organisational ability of Aymé, who was responsible also for creating another important feature of French medical genetics, the Orphanet web-based database and associated information services for families

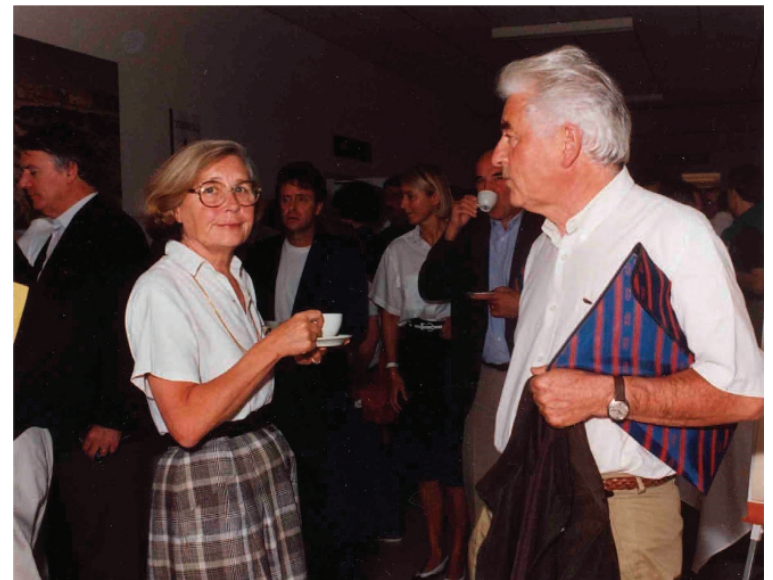

Figure 15 André (1925-2012) and Joelle (1926-2014) Boué, Paris.

with rare genetic disorders. Regarding other centres, I was able to gain a clear picture of how human molecular genetics had evolved in France from Jean-Louis Mandel of Strasbourg [72], complementing that given by Paris based Jean-Claude Kaplan [40]. Interestingly, there seems to have been little influence or direct connection with Monod, Jacob and the other molecular biologists at Institut Pasteur. Kaplan lamented to me that while he was training he attempted to attend Monod's lectures but that these were deliberately scheduled for times when the medical workers could not come!

The above notes are quite inadequate to give the reader a coherent picture of how French human and medical genetics has developed and reached its current high standards. This is partly because to do so would require a very extensive and multifaceted study, but also because perhaps there never has been a clear single narrative to describe. More than in any other country, I was aware of multiple strands involving different people and centres, sometimes conflicting, at others strengthening each other. Elements of this reach deep into French society and include religious background (secular or religious, Jewish or Catholic); gender (prominence of many female workers, yet in the past at least discrimination against them); general political views (left and right wing); centralisation or devolution (Paris and the rest of France); language (Francophone or Anglophone). Many of these issues have subsided since the events I was recording, mostly $30-50$ years ago, but others are taking their place.

As a final note on medical genetics in France, it is relevant to its development that a series of leading people in the field have had prominent political influence. Robert Debré's son, Michel Debré was Prime Minister under de Gaulle between 1959-1962 and reputedly would phone his father each Sunday for advice, whereas Jean-François Mattei was Minister of Health 2002-2004 and responsible both for introducing a major bioethics law and for formalising the role of genetic counsellors as a specific specialty. Jean Frézal was Rector of the University of Paris. More recently, Arnold Munnich has been advisor to former President Sarkozy. Altogether, it is not surprising that human and medical genetics have been at the centre of French life to a degree unusual in the rest of Europe.

\section{United Kingdom}

Looking at the list of my 100 interviews, it is immediately clear that the United Kingdom represents a disproportionate number of them. This bias is in part an artefact, resulting from being myself based in the United Kingdom, with travel to most centres easy and virtually all the significant early workers personally well known to me. Also, I had 
the additional aim of attempting to make my coverage of UK medical genetics, though not of human genetics more broadly, as complete as possible, something that I had realised from the outset would be impracticable for other countries.

I have no intention to try here to give a comprehensive account of how UK human and medical genetics developed; that will have to await another occasion. But I do think that a brief look at the overall patterns and the influences on and differences from continental Europe is worthwhile, as the United Kingdom has undoubtedly had major influences internationally from the very beginnings of genetics.

Thinking first of these early years, before World War 2, much of the general genetics research was in effect human genetics, notably Francis Galton and his 'biometric' colleagues' quantitative research on such normal human characteristics as fingerprints, height and intelligence, even though some of this was flawed. Likewise much early mendelian research, starting with William Bateson and his collaboration with Archibald Garrod on 'inborn errors of metabolism', dating from the beginning of the 20th century, was human disease related. This work had already been incorporated into medical thinking by the 1930s, thanks to monumental contributions such as Julia Bell's Treasury of Human Inheritance volumes, ${ }^{8}$ and published events such as the Royal Society of Medicine's 'Debate on Inheritance and Disease'.

Equally important was the fact that a number of outstanding British geneticists of this period, such as JBS Haldane and Lancelot Hogben, used human data for their more general analyses, leading to key advances such as the first estimates of human mutation rate and the first genetic linkage in humans (haemophilia and colour-blindness). Thus, when life and work resumed at the end of the war, the stage was set for human genetics to emerge as a defined field of study, in contrast to America, which had been turned away from the field by the abuses of eugenics, and most of continental Europe, which was still too devastated to enter the field rapidly.

There is no doubt that the key figure in the early post-war development of human genetics, in the United Kingdom and worldwide, was Lionel Penrose (1898-1972), based at London's Galton Laboratory. Penrose's main work, founded on solid quantitative and

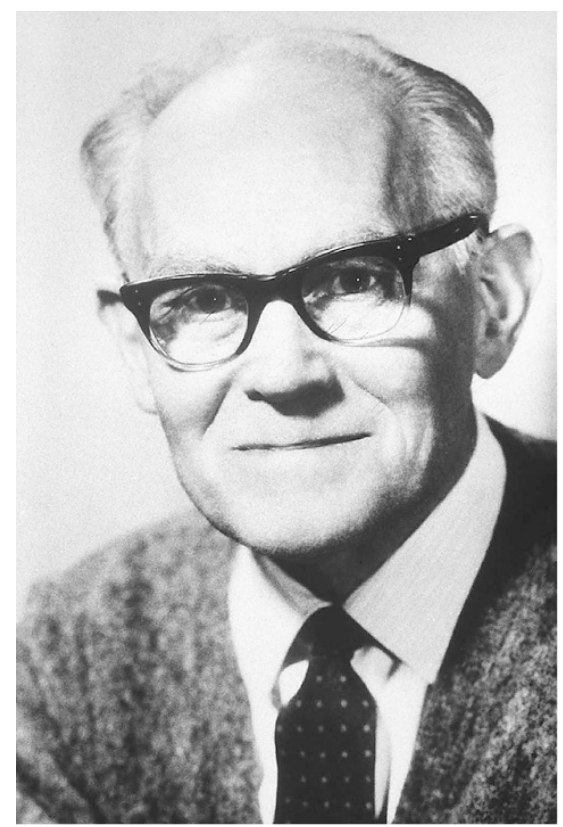

Figure 16 Lionel Penrose (1898-1972) (courtesy Professor Shirley Hodgson). mendelian genetic principles, was in the area of mental handicap, but his unit was a magnet for younger workers, both scientists and clinicians, many of whom became founders in their own countries across Europe (and in America) as well as for workers in Britain, who progressively set up human genetics in their own centres, as posts became available through the university and health systems.

Although Penrose (Figure 16) had died many years before I began my interviews, one can build up a detailed picture of him through the interviews with younger workers who had spent time at the Galton lab. It is remarkable how many key figures across Europe who I interviewed named him as the major influence on their career and life in genetics, (a question that I tried to ask all interviewees), even though they could not always say precisely why. These included Jan Mohr [51], Jean Frézal [44], Marco Fraccaro [09], Herman vanden Berghe [66] and others, as well as those already in the United Kingdom such as Paul Polani [01] and George Fraser [32]. The following quotes speak for themselves.

MF. - intellectually what changed my life was the Galton atmosphere. Penrose, mind you Penrose would never tell you anything directly but he really... I mean my experience at University College, I would never, I couldn't possibly have come back to Italy to find the same situation.

\section{(Marco Fraccaro)}

PSH. — which person in your career has had the biggest influence on the development of your work?

\section{JF. Penrose.}

\section{PSH. That's very interesting.}

JF. Penrose. I was very influenced by Penrose's spirit. (Jean Frézal)

PSH. can you identify, is there one particular person who you feel had the most influence for the development of your work and career in human genetics?

\section{JM. Asked like that, it might be Lionel Penrose.}

PSH. Yes. And would this be for any special reason?

JM. Well, as I mentioned, I liked his concern with the possibility of getting clear answers, although he didn't always get them himself. (Jan Mohr)

PSH. I have talked with a large number of people who have spent time at the Galton. Was that time an important influence for you?

HB. I would say it was like a vision upon a different world. It opened my eyes, absolutely.

(Herman vanden Berghe)

These strongly positive feelings were despite, or perhaps because of, an almost complete lack of organised structure for teaching or research support in the unit, though plenty of both were available if requested. People were encouraged to have their own ideas and to work on them, and to utilise the wide range of expertise in other units nearby. A major factor also was Penrose's strong ethical stance and respect for his patients, as well as respect for facts. After the horrors of war and the abuses of eugenics under the Nazis, this was something that people needed, and it is fortunate for post-war human genetics that its recovery and development were based on Penrose and his unit rather than on others who had been closely associated with pre-war genetics and eugenics. 
a

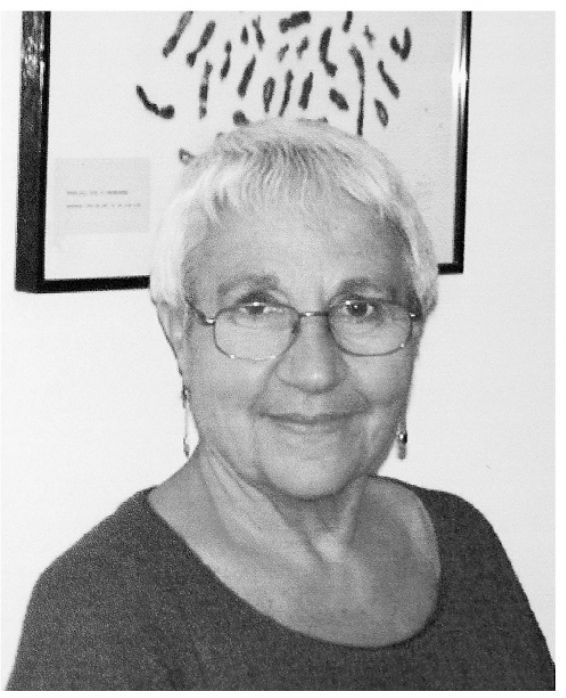

b

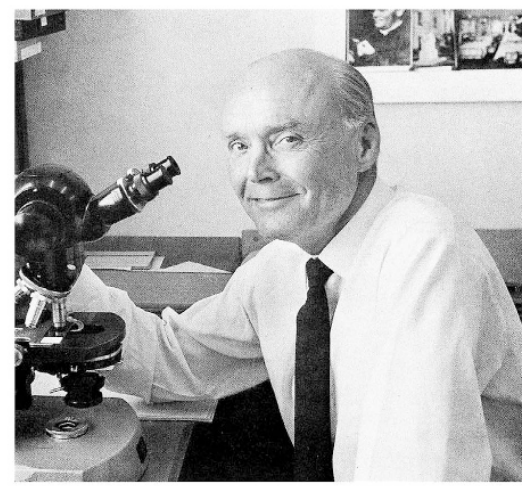

Charles E. Ford

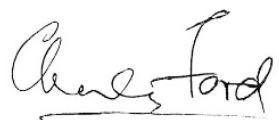

Figure 17 The UK Medical Research Council's radiation research units produced some remarkable workers in human cytogenetics, including (a) Patricia Jacobs, Edinburgh (born 1934) and (b) Charles Ford, Harwell (1912-1999). Photographs courtesy of Professor Patricia Jacobs; S Karger AG, Basel.

A second field of major UK research advances and influence across Europe comes from early developments in human cytogenetics. As with much of Europe, and America too, the impetus came very largely from the threats imposed by exposure to radiation. It had been clear for many years that radiation could cause genetic damage in experimental animals, both somatic and germline; following the Japan atomic explosions, the wider development of nuclear weapons and the radiation fallout into the atmosphere from atomic tests, very real public and political concern developed over genetic and cancer risks at the population level. As chromosome damage was the most visible indicator of this at the cell level, major funding was poured into setting up of cytogenetic laboratories, but also into wider human genetics research.

In the UK the Medical Research Council set up two major centres for radiation related genetic research, one in Edinburgh, with leukaemias and cancers as its principal remit, the other at Harwell, near Oxford, where the main UK experimental nuclear reactor was located and which had mouse genetics as its focus. Both units produced outstanding research involving exceptional people, and perhaps the most valuable general lesson to be learnt comes from the almost total freedom that the unit directors had in their choice of research, often well outside their original remits. This freedom led to major advances in human genetics and the MRC deserves great credit for this too; sadly the inevitable progress of bureaucracy eventually put an end to this laissez faire approach.

I was able to interview several members of these units (Figure 17), including Mary Lyon [18] and Anthony Searle [19] from Harwell and Patricia Jacobs [06] (also her technician Muriel Lee [06]), John Evans [04] and David Harnden [08] from the Edinburgh unit. Charles Ford, perhaps the key founder of British human cytogenetics, was no longer living, but I was able to obtain much information (and many anecdotes) from his former Harwell colleague Ted Evans [15]. I have tried to put the copious information from these interviews together in my book 'First Years of Human Chromosomes' and the full interview transcripts are available on the Genmedhist website, as are audioclips, which are especially pleasurable in bringing back memories of these remarkable people, several now no longer living.
Especially notable discoveries from these units include the 1959 recognition of the XXY chromosome constitution in Klinefelter syndrome by Patricia Jacobs, followed later by XXX and XYY syndromes; At Harwell, Charles Ford, in conjunction with Paul Polani in London, discovered the 45XO basis for Turner syndrome. These discoveries led to numerous collaborations and initiatives across Europe, along with training courses in the new chromosomal techniques, and were a major factor in the development of the European human cytogenetics community.

Although the Galton Laboratory under Penrose and his successors Harry Harris and Elizabeth (Bette) Robson never developed into a centre for medical genetics services, those who trained there helped to provide some of the founders of clinical genetics across the country, as did the London units of Paul Polani (Figure 1) and of Cedric Carter and his predecessor John Fraser Roberts (Figure 18a and b). But perhaps the greatest influence in this process was the Liverpool based institute headed by physician Cyril Clarke (Figure 18c), who also developed close links with Victor McKusick in Baltimore, resulting in a series of hybrid Liverpool/Baltimore medical geneticists mostly from adult internal medicine, who would continue the strongly clinical approach of their parent centres into new units across the United Kingdom. Although none of these three were still living at the time I began my interview series, there is much information on them in the interviews with a number of younger workers who trained with them, including the author. The expansion of the National Health Service gave opportunities for these centres to develop integrated genetic services, laboratory and clinical, on a planned regional basis, a structure that was able to accommodate the new field of human molecular genetics as it became progressively applicable to genetic disorders. This pattern also resulted in a relatively 'flat' and nonhierarchical structure for delivering genetic services, in which these were not subsidiary to the academic system, and within which new professional groups such as non-medical genetic counsellors, could find a home.

A final area in which UK human genetics has influenced the international, particularly the European scene, has been in human molecular genetics research in relation to genetic disorders and its 
a

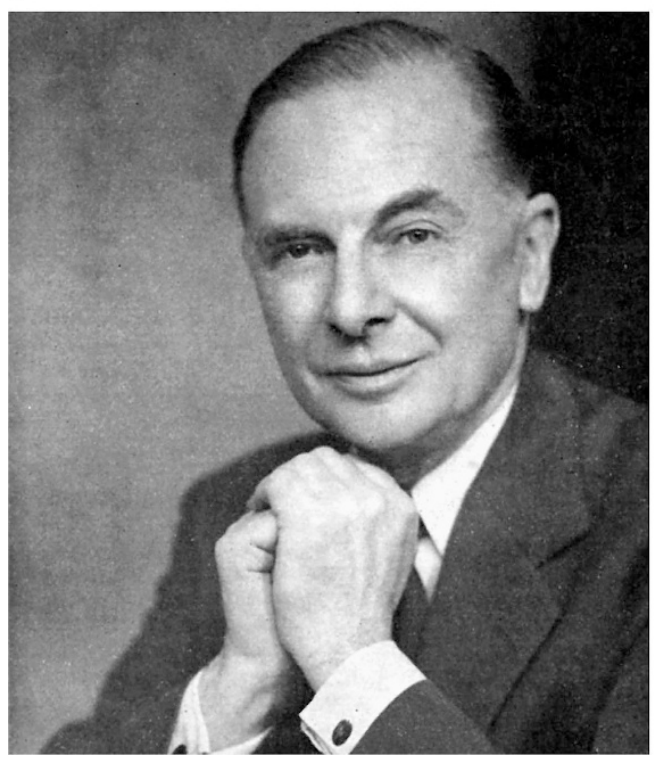

b

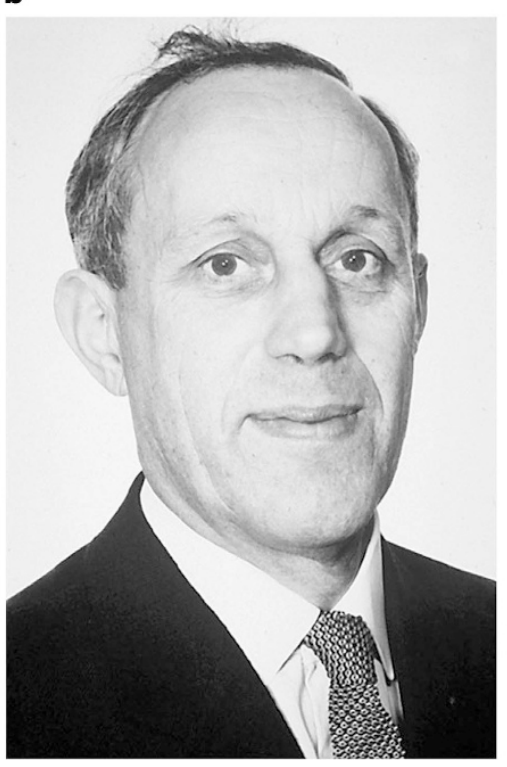

C

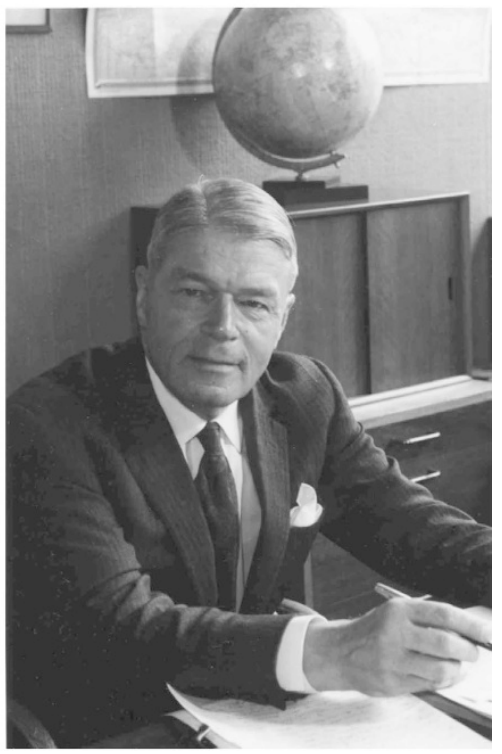

Figure 18 Some pioneers of UK medical genetics (See also Paul Polani, Figure 1). (a) John Fraser Roberts, London, (1899-1987). Courtesy Professor Marcus Pembrey. (b) Cedric Carter, London (1917-1984). Courtesy British Society for Genetic Medicine. (c) Cyril Clarke, Liverpool (1907-2000).

applications in medical genetics practice. Scientists such as Bob Williamson and Kay Davies [61;80] were at the forefront of isolating major disease genes, and in training workers from numerous European centres in the new techniques. I have vivid memories of my own group's collaboration with them and the excitement of the years between 1980 and 1995 when positional cloning allowed the identification of disease genes that before had been entirely inaccessible, such as Huntington's disease and the muscular dystrophies.

Likewise, the use of molecular genetic techniques in diagnosis and prediction has revolutionised medical genetics, and the numerous European collaborations have allowed common policies and high standards to be achieved which have to a large extent avoided the major ethical and practical blunders that might well have occurred had these applications been left to individual centres or commercial forces. The interview with Andrew Read from Manchester [64] illustrates some of these issues, whereas that with Angus Clarke of Cardiff [96] shows how fruitful a careful analysis of the ethical problems can be.

\section{Other European countries}

To ignore almost completely in this article a number of countries, especially those making up most of the southern part of the continent may seem perverse, especially to those working there, and I can only plead the excuse of not having interviewed sufficient workers from these countries to warrant a more general account here. As I have emphasised previously, each country needs to make an attempt to interview its own key pioneers, with my own series marking only a starting point. The few interviews that I did manage to undertake in southern Europe (Giovanni Romeo [73], Marco Fraccaro, Italy [09]; Jorge Sequeiros, Portugal [88]) give an indication of how valuable such a systematic approach might be for these countries. For some countries (eg, Switzerland) historical accounts have already been given (Geiser), ${ }^{29}$ but rarely involving interviews.

My two interviews in Italy, with Marco Fraccaro and Giovanni Romeo, illustrate the diverse origins of Italian human genetics, and interviews with others would be likely to increase this diversity. Fraccaro, from Pavia, had learned genetics under the early geneticist
Buzatti-Traverso (later the renowned population geneticist Luca CavalliSforza would also be based in Pavia); he was greatly influenced by his time in Britain, where he worked first with Penrose at the London Galton Laboratory (see the quotation above), and later with Alan Stevenson in Oxford; in between he took a post in Uppsala where he met Jan Lindsten, and the two established one of the earliest European cytogenetics laboratories, continuing to work together after Fraccaro had returned to set up his own unit in Pavia. This became one of the foremost Italian centres for human cytogenetics, and later for human molecular genetics also. The interview with Fraccaro gives considerable information about early medical genetics elsewhere in Italy.

Giovanni Romeo, by contrast, formed part of the worldwide community of medical geneticists trained by Victor McKusick in Baltimore, with whom he maintained lifelong links, basing the European School of Medical Genetics, first held in Sestri Levante in 1988, largely on McKusick's Bar Harbor 'Short Course in Medical Genetics'. Subsequently Romeo became the first elected President of ESHG.

In Portugal, Jorge Sequeiros represents another Johns Hopkins trainee, learning genetics originally in Porto with Amandio Tavares and subsequently working with neurologist Corino de Andrade on amyloid polyneuropathy, who encouraged him to go to Baltimore. He returned to Porto to develop neurogenetics in particular and has played a key role in establishing medical genetics as a full specialty in Portugal.

In fact, the influence of Victor McKusick on the founding of European Medical Genetics centres and the type of medical genetics that was established in them would make a valuable and interesting study, especially now that McKusick's correspondence and other papers have been archived at Johns Hopkins. Almost 50 years later, this European diaspora of Johns Hopkins graduates (the author is one of them) still maintains close bonds and personal friendships, as can be witnessed at any European meeting.

\section{INTERACTIONS AND DISCONNECTIONS}

In the immediate post-war reconstruction of European science, the initial steps came mainly from individual centres in different countries. 
The need for interactions and collaborations in genetics was indeed the primary reason underlying the founding of ESHG 50 years ago, about which I have written elsewhere in this special issue of the Society's Journal (Harper). ${ }^{5}$ Although it is easy now to disparage the 'minimalist' approach of Jan Mohr and other ESHG founders, the early ESHG meetings helped to create a framework around which more extensive developments could be based.

The most important of these developments for human genetics, perhaps even more than for other areas of science, has of course been the European Union itself, with its programmes of joint research, international workshops, major specific centres and many other initiatives, which together have ensured the leading role in the world for European human genetics generally.

Linked to both the EU and to ESHG, but specific to genetics is the European School of Medical Genetics (now Genetic Medicine), based first at Sestri Levante, then at Bertinoro, Italy, founded by Giovanni Romeo, as described in his interview [73]. This has certainly been one of the main unifying factors in bringing together those working and training in numerous different areas of human and medical genetics.

Other important factors promoting human genetics broadly across Europe have included the far-sighted activities of major charities, such as Rockefeller Foundation in the early years and Wellcome Trust more recently, as well as the French Telethon and comparable initiatives. I wish that I had been able to undertake interviews with key people involved with these activities in different countries; this would be a valuable project for someone. Similarly, the growing role of lay societies for genetic disorders across Europe has been important not only in funding and facilitating research, but as partners alongside professionals in developing policies related to genetic disorders.

As to 'disconnections', without doubt, the greatest disconnection in the history of genetics is that which occurred between Russian genetics and genetics in the rest of the world due to imposition of the fraudulent doctrines of Lysenko, promoted by Stalin, beginning in the mid 1930s and extending well into the 1960s. Russian human genetics has yet fully to recover from this catastrophic chapter.

A somewhat comparable situation resulted at the end of World War 2 in Germany (at least in West Germany as it then was), as a result of the Nazi abuses of eugenics, which involved many prominent human geneticists, many of whom were reinstated in their posts; this resulted in a deep and long lasting revulsion in the general population against the whole field, again something which human genetics in Germany is only now overcoming.

At a more localised level, France illustrates some important disconnections. I have already mentioned the lack of contact between the early molecular biologists and the emerging area of medical genetics, perhaps just one example of a somewhat condescending attitude of basic scientists towards applied or medical workers that remains surprisingly widespread. The understandable but unhelpful insistence of some prominent French geneticists (Lejeune was a notable example) on using the French language rather than English certainly hindered many of the earlier French workers in the field and limited the development of their links with Anglophone centres.

And sadly, at a personal as well as a general level, the impending loss of the United Kingdom from the European Union is bound to damage the invaluable links between Britain and the rest of Europe forged over the past half century, which for genetics have been especially fruitful.

\section{SOME GENERAL CONCLUSIONS}

I learned a great deal from undertaking my interview series, the most important things being how little I had known previously and how much I still had to learn. Still, I do feel that there are some clear conclusions that can be drawn from what I have managed to do, and I shall try to summarise them here.

First, European human and medical genetics over the past half century have undoubtedly been a success, both in scientific terms and also in relation to medical advances. Although there were some sound foundations, (as well as some disastrous misapplications) before World War 2, the field has essentially developed from virtually nothing during the professional lifetimes of many of those who I was able to interview, and is now a major force in both science and medicine.

Second, human genetics has crossed both geographical and professional boundaries to a remarkable degree, and has been marked by a high degree of cooperation and collaboration across Europe and generally across the world. The interviews show how much time and effort many of the founders of the field spent in trying to promote the specialty as a whole, not just their own interests, with a strong tradition of mutual help, especially in medical genetics services, though naturally competition in research has not been absent. The field has also shown a strong talent for opportunism where funding is concerned, both for research and for its translation into medical services. Perhaps this is because over most of this time funding has been far from easy and has required ingenuity to obtain.

A third aspect that in my view should be regarded as a success is the recognition of the numerous ethical problems that exist, not only in human genetics research but in applications by medical geneticists and by wider medical professionals. In the early years the main focus was on prenatal diagnosis, as related to abortion; the interviews with Kåre Berg and with Belgian and French workers show how a cautious and responsible approach gradually overcame entrenched opposition from religious groups. The advent of molecular genetic testing, particularly predictive testing for adult diseases such as Huntington's disease, produced a further series of ethical difficulties; again these have been largely avoided or overcome by a combination of awareness and detailed collaborative analysis, something that the involvement of social scientists has also helped with. Now the main challenge is to ensure that other medical professionals, increasingly involved in the new applications of genomics, also follow the standards and guidelines that have evolved.

On the debit side, my interviews showed clearly how badly many women of outstanding ability were treated, something that is now diminished and certainly less overt, but probably not yet extinct. And, as might be expected from interviews with founders who had built up successful units from small beginnings (often just themselves), some of them, though by no means all, found it difficult to accept the limitations of retirement and no longer being in charge of things.

All in all, my broad conclusion from 50 years in the field of human and medical genetics, and in particular from my interview series, is that the field has not only been outstanding in its scientific and medical successes over the past half century, but that its pioneers have been truly remarkable individuals. Of course, being from the field myself and interviewing people about their own work and achievements, this conclusion is bound to be a biased one; yet I do not feel that it is far from the truth, whereas the fragmentary picture of the beginnings and development of the field across Europe, which I have given here is unlikely to be contradicted by written or other evidence. 
Certainly, for me personally, undertaking the interview series has been one of the most rewarding parts of my career in medical genetics, especially coming at a relatively late point when one might have felt that one had little more to contribute. I hope and sincerely think that others, after reading the interview transcripts, will find enjoyment and, for the most part pride, in the stories told by these pioneers.

\section{CONFLICT OF INTEREST}

The author declares no conflict of interest.

\section{ACKNOWLEDGEMENTS}

More than anyone else I should like to thank all those people who I interviewed as part of this series. Their remarkable welcome and hospitality made the interviews a pleasure and privilege, quite apart from the value of what they told me. It was abundantly clear that they had all found their lives and careers in human and medical genetics highly rewarding and I hope that by recording their memories here some of this spirit will be apparent to the readers of the interview transcripts. Many people helped to facilitate the interviews, notably Arnold Munnich and his colleagues at Hopital Necker in Paris, Ulf Kristoffersson in Lund and Yevgeny Ginter and colleagues in Russia, but others also. The staff of ESHG were likewise most helpful and supportive, especially in funding my visits to the Copenhagen archive. Photos not otherwise acknowledged are either the gift of the interviewee or were taken by the author at the time of interview. Back in Cardiff, a series of people helped with transcribing interviews, notably June Williams, Joanne Richards and Carole Rabbaiotti, mostly in 'spare time' from their more official duties. Without exception they all told me that they found the transcribing and the interviews themselves more interesting than anything else they were meant to be doing! Professor Tilli Tansey also kindly helped to fund some of the transcriptions through her Wellcome Trust grant. Christine Holness brought much scattered material together to form the basis of the present article. I am especially grateful, finally, to Cardiff University's Institute of Medical Genetics for giving me facilities, especially IT support, without which I very much doubt that I should have been able to complete the work.

1 Harper PS: Recorded interviews with human and medical geneticists. Hum Genet 2017; 136: 149-164.

2 Harper PS: First Years of Human Chromosomes. Oxford: Scion Press, 2006.

3 Dronamraju K (ed.): The Foundations of Human Genetics. Springfield II Charles C Thomas, 1989.

4 Harper PS: The Oldest Society for Genetics in the World? Genetics Society Newsletter 2005, p 41.

5 Harper PS: The European Society of Human Genetics: beginnings, early history and development over its first 25 years. European Journal of Human Genetics 2017, (in press).

6 Mohr J: A study of Linkage in Man. Copenhagen: Munksgaard, 1951.
7 Eiberg H, Mohr J, Schmiegelow K, Nielsen LS, Williamson R: Linkage relationships of paraoxonase (PON) with other markers: indication of PON-cystic fibrosis synteny. Clin Genet 1985; 28: 265-271.

8 Bell J: Huntington's chorea. In: Fisher RA (ed.): The Treasury of Human Inheritance Vol 1 (part 4) Cambridge University Press, 1934, pp 1-67.

9 Macklin MT: Human tumors and their inheritance. Can Med Assoc J 1932; 27: 182-187.

10 Tjio JH, Levan A: The chromosome number of man. Hereditas 1956; 422: 1-6.

11 Mohr OL: Heredity and Disease. New York: Norton, 1934.

12 Hogben A, Hogben A (eds): Lancelot Hogben, Scientific Humanist: an Unauthorised Biography. Woodbridge: Suffolk. Merlin Press, 1998.

13 Hulten M: Numbers, bands and recombination of human chromosomes: historical anecdotes from a Swedish student. Cytogenet Genome Res 2002; 96: 14-19.

14 Mitelman F: Catalog of Chromosome Aberrations in Cancer. New York: Alan Liss, 1983.

15 Caspersson T, Lomakka G, Zech L: The 24 fluorescence patterns of the human metaphase chromosomes: distinguishing characters and variability. Hereditas 1971; 67: 89-102.

16 Norio R: Finnish Disease heritage 1: characteristics, causes, background. Hum Genet 2003; 112: 441-456.

17 Broberg G, Roll-Hansen N (eds): Eugenics and the Welfare State: Sterilisation Policy in Denmark, Sweden, Norway and Finland. East Lansing: Michigan State University Press, 1996.

18 Jones EM, Tansey EM: Clinical molecular genetics in the UK c1975-c2000. London: Queen Mary University of London, 2014.

19 Jones EM, Tansey EM: The human gene mapping workshops. London: Queen Mary University of London, 2015.

20 Winiwarter $\mathrm{H}$ : Etudes sur la spermatogenèse humaine. Arch Biol 1912; 27: 91-189.

21 Vogel F: Genetics and mutation rate of retinoblastoma (glioma retinae). With general remarks on methods of determining mutation rate in humans. Z Mensch Vererb Konstitutions/ 1954; 32: 308-336.

22 Vogel F, Motulsky A: Human Genetics. Problems and Approaches. New York: Springer, 1979.

23 Medvedev Z: The Rise and Fall of TD Lysenko. New York: Columbia University Press, 1969.

24 Harper PS: A Short History of Medical Genetics. New York: Oxford University Press, 2008

25 Medvedev Z: Nuclear Disaster in the Urals. New York: Norton, 1979.

26 Laxova R: Letter to Alexander. Cincinnati: Custom Editorial Productions, 2001.

27 Gautier M, Harper PS: Fiftieth anniversary of trisomy 21: returning to a discovery. Hum Genet 2009; 126: 317-324.

28 Gilgenkrantz S, Rivera EM: The history of cytogenetics: portraits of some pioneers. Ann Genet. 2003; 46: 443-442.

29 Geiser M: Medical Genetics and scientific expertise in Switzerland in the 1940s. Am J Med Genet 2002; 115: 94-101.

(i) $(9)$ This work is licensed under a Creative Commons Attribution-NonCommercial-NoDerivs $\quad 4.0$ International License. The images or other third party material in this article are included in the article's Creative Commons license, unless indicated otherwise in the credit line; if the material is not included under the Creative Commons license, users will need to obtain permission from the license holder to reproduce the material. To view a copy of this license, visit http://creativecommons.org/licenses/bync-nd/4.0/

(C) The Author(s) 2017 